\title{
Melatonin and Its Agonist Ramelteon in Alzheimer's Disease: Possible Therapeutic Value
}

\author{
Venkatramanujam Srinivasan, ${ }^{1,2}$ Charanjit Kaur, ${ }^{3}$ Seithikurippu Pandi-Perumal, ${ }^{4}$ \\ Gregory M. Brown, ${ }^{5}$ and Daniel P. Cardinali ${ }^{6}$
}

${ }^{1}$ Sri Sathya Sai Medical Educational and Research Foundation, Prasanthi Nilayam, 40- Kovai Thirunagar, Coimbatore 641014, India

${ }^{2}$ Department of Physiology, Faculty of Medicine, Karpagam University, Eachanari, Coimbatore 641021, India

${ }^{3}$ Department of Anatomy, Yong Loo Lin School of Medicine, Block MD10, Medical Drive, National University of Singapore, Singapore 117597

${ }^{4}$ Somnogen Inc., College Street, Toronto, ON, Canada M6H 1 C5

${ }^{5}$ Centre for Addiction and Mental Health, Department of Psychiatry, University of Toronto, Toronto, ON, Canada M5T 1RS

${ }^{6}$ Departmento de Docencia e Investigación, Facultad de Ciencias Médicas, Pontificia Universidad Católica Argentina, Avenida Alicia Moreau de Justo 1500, $4^{\circ}$ piso, 1107 Buenos Aires, Argentina

Correspondence should be addressed to Daniel P. Cardinali, danielcardinali@fibertel.com.ar

Received 21 September 2010; Revised 8 October 2010; Accepted 27 October 2010

Academic Editor: Anthony R. White

Copyright ( $) 2011$ Venkatramanujam Srinivasan et al. This is an open access article distributed under the Creative Commons Attribution License, which permits unrestricted use, distribution, and reproduction in any medium, provided the original work is properly cited.

\begin{abstract}
Alzheimer's disease (AD) is an age-associated neurodegenerative disease characterized by the progressive loss of cognitive function, loss of memory and insomnia, and abnormal behavioral signs and symptoms. Among the various theories that have been put forth to explain the pathophysiology of $\mathrm{AD}$, the oxidative stress induced by amyloid $\beta$-protein $(\mathrm{A} \beta)$ deposition has received great attention. Studies undertaken on postmortem brain samples of AD patients have consistently shown extensive lipid, protein, and DNA oxidation. Presence of abnormal tau protein, mitochondrial dysfunction, and protein hyperphosphorylation all have been demonstrated in neural tissues of AD patients. Moreover, AD patients exhibit severe sleep/wake disturbances and insomnia and these are associated with more rapid cognitive decline and memory impairment. On this basis, the successful management of $\mathrm{AD}$ patients requires an ideal drug that besides antagonizing $\mathrm{A} \beta$-induced neurotoxicity could also correct the disturbed sleep-wake rhythm and improve sleep quality. Melatonin is an effective chronobiotic agent and has significant neuroprotective properties preventing $\mathrm{A} \beta$-induced neurotoxic effects in a number of animal experimental models. Since melatonin levels in AD patients are greatly reduced, melatonin replacement has the potential value to be used as a therapeutic agent for treating AD, particularly at the early phases of the disease and especially in those in whom the relevant melatonin receptors are intact. As sleep deprivation has been shown to produce oxidative damage, impaired mitochondrial function, neurodegenerative inflammation, and altered proteosomal processing with abnormal activation of enzymes, treatment of sleep disturbances may be a priority for arresting the progression of $\mathrm{AD}$. In this context the newly introduced melatonin agonist ramelteon can be of much therapeutic value because of its highly selective action on melatonin $\mathrm{MT}_{1} / \mathrm{MT}_{2}$ receptors in promoting sleep.
\end{abstract}

\section{Introduction}

Alzheimer's disease (AD), a major age-associated neurodegenerative disease, is characterized by progressive loss of cognitive function, loss of memory, impaired synaptic function, and a massive brain cell loss that ultimately results in premature death. Although the exact cause of the disease is under intense investigation, the prevailing hypothesis proposes that the deposition of amyloid $\beta$-protein- (A $\beta$-)containing senile plaques and of intracellular neurofibrillary tangles major etiological factors in $\mathrm{AD}$ [1]. Deposition of amyloid plaques causes cell death by inducing mitochondrial dysfunction and oxidative stress [2]. A $\beta$ deposition initiates the flavoenzyme-dependent increase of hydrogen peroxide $\left(\mathrm{H}_{2} \mathrm{O}_{2}\right)$ and lipid peroxides that increase free radical generation $[3,4]$. Neural tissues of AD patients exhibit increased levels 
of end products of peroxidation such as malondialdehyde, 4-hydroxynonenal, or carbonyls. Though $\mathrm{A} \beta$ contributes directly or indirectly to neuronal degeneration, its potential to cause $\mathrm{AD}$ depends on individual's susceptibility to $\mathrm{A} \beta$ mediated toxicity [5].

Mitochondrial dysfunction plays an important role in $\mathrm{AD}$ and the link among impaired mitochondrial function, tau phosphorylation, and $\mathrm{A} \beta$ amyloidosis is increasingly recognized as a major phenomenon in $\mathrm{AD}$ physiopathology $[2,6,7]$. A $\beta$ accumulation and neurofibrillary tangles composed of tau protein induce functional deficits of the respiratory chain complexes thereby resulting in mitochondrial dysfunction and oxidative stress (the "A $\beta$ cascade hypothesis of $\mathrm{AD}$ "). It is interesting to note that women are more vulnerable to $\mathrm{AD}$ than men, presumably because the mitochondria are protected by estrogens against $\mathrm{A} \beta$ toxicity [8].

Indeed, aging and neurodegenerative diseases are accompanied by abnormal levels of oxidation of proteins, lipids, and nucleic acids [9-11]. Mechanisms such as chronic inflammation associated with the release of cytokines and trace element neurotoxicity have also been suggested as possible contributory factors underlying the physiopathologic events of AD [12-14]. Membrane disruption and induction of apoptosis by caspase enzymes have also been implicated [15].

In addition to cognitive and memory dysfunction, sleepwake and other circadian rhythm dysregulation, are commonly seen in AD [16-19]. These circadian rhythm disturbances are associated with disturbed melatonin rhythmicity and decreased circulating and brain melatonin levels [2022]. It is hypothesized that the decreased levels of melatonin, in fact, could contribute to the pathophysiology of $\mathrm{AD}$ in view than melatonin combines chronobiotic with effective antioxidant, anti-inflammatory, and antifibrillogenic properties [23].

Among the factors known to suppress the production of melatonin by the pineal gland, hypoxia deserves to be considered [24]. Reduced production of melatonin has been reported to occur in other ischemic conditions such as coronary artery disease or severe congestive heart failure [2527]. Hypoxia may play a role in the pathogenesis of $\mathrm{AD}$ as it can induce formation of $\mathrm{A} \beta$ [28-30]. The role of hypoxia in potentiating $\mathrm{AD}$ is supported by the observation that patients suffering from cardiorespiratory disorders, cerebral ischemia or stroke are much more susceptible to development of dementias including $\mathrm{AD}$ [31]. It is remarkable that the daily administration of melatonin reduces the hypoxia induced $\mathrm{A} \beta$ generation in the rat hippocampus [32].

With this background, the replacement of brain melatonin levels has been suggested as a way arresting the progress of $\mathrm{AD}$ and for correcting the circadian and sleep-wake disturbances associated with the disease. As melatonin is a short-lived molecule having a limited duration of action (half life $=0.54-0-67 \mathrm{~h}[33]$ ), analogs with a high affinity for melatonin receptors and a longer duration of action have been synthesized with a potential therapeutic efficacy to treat insomnia and psychiatric disorders like depression and bipolar affective disorder [34]. Ramelteon was the first of these molecules approved by the U.S. Food and Drug Administration to be used in the treatment of insomnia [35] and its potential use in $\mathrm{AD}$ together with that of melatonin is discussed in this review article.

\section{Melatonin in AD}

Melatonin is synthesized both in the pineal gland and in a number of peripheral organs and tissues by a process starting with tryptophan conversion to serotonin (reviewed in [36]). Serotonin is then acetylated to form $\mathrm{N}$-acetylserotonin by the enzyme arylakylamine $\mathrm{N}$-acetyltransferase while $\mathrm{N}$ acetylserotonin is converted into melatonin by the enzyme hydroxyindole-O-methyl transferase $[37,38]$. Once formed melatonin is not stored within the pineal gland it diffuses into the capillary blood and the cerebrospinal fluid (CSF) $[39,40]$. CSF melatonin values are nearly 30 times higher than those in the blood; thus, the brain tissue has a higher melatonin concentration than any other tissue in the body [41].

Regional distribution of melatonin in different areas of the brain varies and early studies have shown that hypothalamic melatonin concentrations are nearly fifty times higher than in plasma [42-44]. While tissue melatonin only exhibits a moderate circadian variation, circulating melatonin exhibits most pronounced circadian rhythm with highest levels occurring at night and very low levels during daytime [36].

Circulating melatonin is metabolized mainly in the liver via hydroxylation in the C6 position by cytochrome $\mathrm{P}_{450}$ monooxygenases (CYP1A2;CYP1A1) [45]. It is thereafter conjugated with sulphate to form 6-sulfatoxymelatonin (aMT6S), the main metabolite of melatonin in urine. In the brain, melatonin is metabolized to kynuramine derivatives like $N^{1}$-acetyl- $N^{2}$-formyl-5-methoxykynuramine (AFMK) $[46,47]$. In several tissues melatonin is also nonenzymatically metabolized to cyclic 3-hydroxy melatonin [48].

Melatonin is involved in the control of various physiological functions such as circadian rhythmicity $[49,50]$, sleep regulation $[51,52]$, immune function $[53,54]$, antioxidant defense $[55,56]$, control of reproduction [57-59], inhibition of tumor growth $[60,61]$, and control of human mood $[62,63]$. Melatonin participates in many of these functions by acting through $\mathrm{G}$-protein membrane receptors, the $\mathrm{MT}_{1}$ and $\mathrm{MT}_{2}$ melatonin receptors [64-66]. Nuclear melatonin receptors belonging to the $\mathrm{RZR} / \mathrm{ROR} \alpha$ receptor class have also been described $[56,67,68]$. Melatonin also acts directly on the cells without the intervention of any of these receptors by binding to intracellular proteins like calmodulin [69] or tubulin [70]. In general, the free radical scavenging action of melatonin does not involve receptors except for the induction of synthesis of some antioxidant enzymes like $\gamma$-glutamylcysteine synthase that involves RZR/ROR $\alpha$ receptors [71].

In view of the involvement of oxidative stress in $\mathrm{AD}$, melatonin represents an interesting neuroprotective agent as it antagonizes oxidative stress both in a direct and in an indirect way $[55,56,72,73]$. In the N2a murine neuroblastoma cell model Pappolla et al. [74] first demonstrated 
that coincubation of $\mathrm{A} \beta$ with melatonin significantly reduced several features of apoptosis like cellular shrinkage or formation of membrane blubs. In a number of studies melatonin prevented the death of neuroblastoma cells exposed to $\mathrm{A} \beta$ $[5,75,76]$.

Several animal models of AD have been used to study the possible antoxidative and antiapoptotic actions of melatonin in arresting neuronal lesions. Okadaic acid induces physiological and biochemical changes similar to those seen in $\mathrm{AD}$. Increased levels of 4-hydroxynonenal in cultured neuronal cells have been found following administration of okadaic acid [77]. After the administration of antioxidants like melatonin or vitamin $\mathrm{C}$, the effects of okadaic acid on NIE 115 neuronal cells were prevented effectively [78]. Melatonin was more effective than vitamin $C$, since it not only prevented the free radical-induced damage with greater efficiency but also increased the activity of the antioxidant enzymes glutathione-S transferase and glutathione reductase [78].

Several studies indicate that the apoptosis of astrocytes contribute to the pathogenesis of AD (sees [79]). Astrocytes exhibit tau phosphorylation and activation of stress kinases as seen in AD pathology. They also produce apolipoprotein $\mathrm{E} 4$ (apoE4) that aggravates $\mathrm{A} \beta$ neurodegenerative effects $[80,81]$. During interaction with $\mathrm{A} \beta$, astrocytes lose control over NO production leading to the neurotoxic peroxynitrate formation. By treating the C6 astroglioma cells with melatonin, the increase in NO production induced by $\mathrm{A} \beta$ was effectively prevented [82].

\section{Molecular Mechanisms of Melatonin's Anti-Amyloid Actions}

Melatonin not only reduced apoptosis but also exerts its antiamyloid actions through additional mechanisms. One of them is by preventing $A \beta$-induced mitochondrial damage and disruption of respiration. Melatonin administration prevented $\mathrm{A} \beta$ action on mitochondrial DNA proteins and level of lipid peroxidation [75]. In this aspect it is interesting to note that melatonin's metabolite AFMK also offered protection from $\mathrm{A} \beta$-induced mitochondrial oxidative stress [83] although a higher concentration was needed.

Melatonin inhibits the formation of amyloid fibrils as demonstrated by different techniques $[84,85]$. The structural analog of melatonin indole-3-propionic acid not only shares the radical scavenging activity of melatonin [86] but also exhibits similar or even higher antifibrillogenic activity [87].

Several lipoproteins can modulate fibrillogenesis [88]. Melatonin was shown to reverse the profibrillogenic activity of apoE4 and to antagonize the neurotoxic combinations of $\mathrm{A} \beta$ and apoE4 or apoE3 [83]. ApoE4 is also produced by astrocytes and aggravates $\mathrm{A} \beta$ effects showing thereby the mutual interaction of $\mathrm{A} \beta$ protein and apo-E4 in the astrocyte-neuron interactions [81]. The antifibrillogenic effects of melatonin and its metabolites were observed not only in vitro but also in vivo in transgenic mouse models $[84,89,90]$. Protection from $\mathrm{A} \beta$ toxicity was observed, especially at the mitochondrial level.
As mentioned above, chronic intermittent hypoxia has been shown to induce $A \beta$ protein generation by upregulating the APP processing enzymes BACE and PSEN-1 [28-30]. The daily administration of melatonin $(10 \mathrm{mg} / \mathrm{kg})$ prior to a short-term hypoxia prevented the generation of $\mathrm{A} \beta$ protein but it did not reduce the increase of HIF-1 transcription factor induced by hypoxia [32]. Hence it was suggested that melatonin's neuroprotective effect against amyloid- $\beta$-peptide was due to its direct free radical scavenging properties actions [32].

Another manifestation of $\mathrm{AD}$ studied in experimental models is the expression of protein hyperphosphorylation and cytoskeletal disorganization. Calyculin A, an inhibitor of protein phosphatases (PP), was used in neuroblastoma N2 cells to examine this point. Calyculin A resulted in activation of glycogen synthase kinase 3 (GSK-3), a redox-controlled enzyme involved in various regulatory mechanisms of the cell, and the consequent hyperphosphorylation of tau [91]. Melatonin administration decreased oxidative stress and tau hyperphosphorylation and reversed GSK-3 activation showing thereby that it not only acts as an antioxidant but also interferes with the phosphorylation system, particularly stress kinases [91].

The inhibition of PP-2A and PP-1 brought about by calyculin A caused hyperphosphorylation of tau and of neurofilaments, synaptophysin loss, and spatial memory retention impairment, an effect counteracted by the administration of melatonin i.p. for 9 days before calyculin injection [92]. Melatonin also partially reversed the phosphorylation of the catalytic subunit of PP-2A at tyrosine 307 (Y307) crucial site regulating the activity of $\mathrm{PP}-2 \mathrm{~A}$, and reduced malondialdehyde levels induced by calyculin A [92]. Melatonin also attenuated tau hyperphosphorylation induced by wortmannin $[93,94]$ and isoproterenol [95].

Tyrosine kinase (trk) receptors, important elements of the phosphorylation system, as well as neurotrophins, are affected by $\mathrm{A} \beta$ and other oxidotoxins and melatonin normalized in neuroblastoma cells trk and neurotrophin expression [96]. Recent studies using organotypic hippocampal studies confirmed that the presence of melatonin $(25-100 \mu \mathrm{M})$ prevented the cell damage induced by exposure to $\mathrm{A} \beta$ reducing the activation of GSK-3 $\beta$, the phosphorylation of tau protein, and the $\mathrm{A} \beta$-induced increases of TNF- $\alpha$ and IL-6 levels [97]. The chronobiological aspects of melatonin$\mathrm{A} \beta$ interaction are underlined by a study describing the protective effect of melatonin against the circadian changes produced by $\mathrm{A} \beta_{25-35}$ microinjection into the suprachiasmatic nuclei (SCN) of golden hamsters [98].

\section{Potential Therapeutic Value of Melatonin in AD}

A number of studies in $\mathrm{AD}$ patients have indicated that there is a profound disturbance in sleep/wake cycle associated with the progression of the disease. Cross-sectional studies reveal that sleep disturbances are associated with memory and cognitive impairment. [16-19]. A severe disruption of the circadian timing system occurs in $\mathrm{AD}$ as indicated by 
alterations in numerous overt rhythms like body temperature, glucocorticoids, and/or plasma melatonin [22, 99, 100]. The internal desynchronization of rhythms is significant in AD patients [101, 102].

"Sundowning" is a chronobiological phenomenon observed in $\mathrm{AD}$ patients in conjunction with sleep-wake disturbances, including symptoms like disorganized thinking, reduced ability to maintain attention to external stimuli, agitation, wandering, and perceptual and emotional disturbances, all appearing in late afternoon or early evening [99, 103, 104]. Chronotherapeutic interventions such as exposure to bright light and/or timed administration of melatonin in selected circadian phases alleviated sundowning symptoms like wandering, agitation and delirium and also improved sleep-wake patterns of $\mathrm{AD}$ patients [105].

A number of studies have revealed that melatonin levels are lower in $\mathrm{AD}$ patients as compared to age-matched control subjects $[20-22,106]$. The decreased CSF melatonin levels of $\mathrm{AD}$ patients were attributed to decreased melatonin production. CSF melatonin levels decreased even in preclinical stages (Braak stages-1) when patients did not manifest cognitive impairment [107] suggesting thereby that reduction in CSF melatonin may be an early marker (and cause) for incoming $\mathrm{AD}$. The decrease of melatonin levels in $\mathrm{AD}$ was attributed to a defective retinohypothalamic tract or SCN-pineal connections [108]. The impaired melatonin production at night correlates significantly with the severity of mental impairment of demented patients [109]. As AD patients have profound deficiency of endogenous melatonin, replacement of levels of melatonin in the brain could be a therapeutic strategy for arresting the progress of the disease. Melatonin's neuroprotective and vasoprotective properties would help in enhancing cerebral blood flow and would help to improve the clinical condition of AD patients [23].

Sleep disturbances exacerbate memory and cognitive impairment [110]. Therefore, optimization in management of sleep disturbances is of paramount importance in treating AD patients. In an initial study on $14 \mathrm{AD}$ patients with 6$9 \mathrm{mg}$ of melatonin given for 2-3 year period it was noted that melatonin improved sleep quality [111]. Sundowning, diagnosed clinically, was no longer detectable in 12 out of 14 patients. Reduction in cognitive impairment and amnesia was also noted. This should be contrasted with the significant deterioration of the clinical conditions expected from patients after $1-3$ year of evolution of AD $[111,112]$.

Several studies support the efficacy of melatonin in treating sleep and chronobiologic disorders in $\mathrm{AD}$ patients (Table 1). The administration of melatonin ( $6 \mathrm{mg} /$ day) for 4 weeks to $\mathrm{AD}$ patients reduced nighttime activity as compared to placebo [113]. An improvement of sleep and alleviation of sundowning were reported in $11 \mathrm{AD}$ patients treated with melatonin ( $3 \mathrm{mg}$ /day at bedtime) and evaluated by using actigraphy [114]. Improvement in behavioral signs was reported with use of 6-9 $\mathrm{mg}$ /day of melatonin for 4 months in $\mathrm{AD}$ patients with sleep disturbances [115].

In a double blind study conducted on $\mathrm{AD}$ patients it was noted that $3 \mathrm{mg} /$ day of melatonin significantly prolonged actigraphically evaluated sleep time, decreased activity in night, and improved cognitive functions [119]. In a multicenter, randomized, placebo-controlled clinical trial of a sample of $157 \mathrm{AD}$ patients with sleep disturbances, melatonin or placebo was administered for a period of 2 months [120]. In actigraphic studies a trend to increased nocturnal total sleep time and decreased wake after sleep onset was noted in the melatonin-treated group. On subjective measures by caregiver ratings significant improvement in sleep quality was noted with $2.5 \mathrm{mg}$ sustained release melatonin relative to placebo [120].

Negative results with the use of melatonin in fully developed $\mathrm{AD}$ were also published. For example, in a study in which melatonin ( $8.5 \mathrm{mg}$ fast release and $1.5 \mathrm{mg}$ sustained release) was administered at $10.00 \mathrm{PM}$ for 10 consecutive nights to patients with $\mathrm{AD}$, no significant difference was noticed with placebo on sleep, circadian rhythms and, agitation [124]. Although the lack of beneficial effect of melatonin in this study on sleep could be attributed to the short period of time examined, it must be noted that large interindividual differences between patients suffering from a neurodegenerative disease are not uncommon. It should be also taken into account that melatonin, though having some sedating and sleep latency-reducing properties, does not primarily act as a sleeping pill, but mainly as a chronobiotic.

Since the circadian oscillator system is obviously affected in $\mathrm{AD}$ patients showing severe sleep disturbances, the efficacy of melatonin should be expected to depend on disease progression. In a recent paper one of us summarized the published data concerning melatonin treatment of $\mathrm{AD}$ patients [125] (Table 1). Eight reports (5 open-label studies, 2 case reports) $(N=89$ patients $)$ supported a possible efficacy of melatonin: sleep quality improved and in patients with $\mathrm{AD}$ sundowning was reduced and cognitive decay showed less progression. In 6 double blind, randomized placebocontrolled trials $(N=210)$ sleep was objectively measured by wrist actigraphy and additionally neuropsychological assessment and sleep quality were subjectively evaluated. Sleep quality increased and sundowning decreased significantly and cognitive performance improved in 4 studies $(N=143)$ whereas there was absence of effects in 2 studies $(N=67)$ [125]. Therefore, the question whether melatonin has a causal value in preventing or treating $\mathrm{AD}$, affecting disease progression of the neuropathology and the driving mechanisms, remains unanswered. Doubleblind multicenter studies are needed to further explore and investigate the potential and usefulness of melatonin as an antidementia drug. Its apparent usefulness in symptomatic treatment, concerning sleep, sundowning, and so forth, even in a progressed state, further underlines the need for such decisive studies.

It has been shown that with degeneration of the SCN, the master body clock, there is a decrease in the expression of $\mathrm{MT}_{1}$ receptors so that strength of melatonin as a synchronizing agent is reduced [126]. Moreover the input of neural pathways involved in entrainment (synchronization) of the central clock may become dysfunctional or less sensitive during aging and even more so in $\mathrm{AD}$ [127]. In a large multicentre trial only a nonsignificant trend to improvement in the circadian rhythm disturbance of $\mathrm{AD}$ is when treatment 
TABLE 1: Clinical studies on melatonin efficacy in AD.

\begin{tabular}{lllll}
\hline Design & $\begin{array}{l}\text { Subjects } \\
(\mathrm{M}, \mathrm{F})\end{array}$ & Treatment & $\begin{array}{l}\text { Study's } \\
\text { duration }\end{array}$ & Measured \\
\hline & & & \\
$\begin{array}{l}\text { Open-label } \\
\text { study }\end{array}$ & $\begin{array}{l}10(6,4) \\
\text { demented } \\
\text { patients }\end{array}$ & $\begin{array}{l}\text { 3 mg melatonin } \\
\text { p.o./daily at bed } \\
\text { time }\end{array}$ & 3 weeks & $\begin{array}{l}\text { Daily logs of sleep and } \\
\text { wake quality completed by } \\
\text { caretakers }\end{array}$
\end{tabular}

Results

Reference

Seven out of ten dementia patients

having sleep disorders treated with

melatonin showed a significant

decrease in sundowning and

reduced variability of sleep onset time

At the time of assessment, a significant improvement of sleep quality was found. Sundowning was $\begin{array}{lll}\text { Open-label } & 14(8,14) & 9 \mathrm{mg} \text { melatonin } \\ \text { study } & \mathrm{AD} \text { patients } & \text { p.o./daily at bed } \\ \text { time }\end{array}$ time
Daily logs of sleep and

22 to 35 wake quality completed by caretakers.

Neuropsychological assessment. not longer detectable in 12 patients and persisted, although attenuated in 2 patients. Clinically, the patients exhibited lack of progression of the cognitive and behavioral signs of the disease during the time they received melatonin.

\begin{tabular}{|c|c|c|c|c|}
\hline Case report & $\begin{array}{l}\text { Monozygotic } \\
\text { twins with } \\
\mathrm{AD} \text { of } 8 \\
\text { years } \\
\text { duration }\end{array}$ & $\begin{array}{l}\text { One of the patients } \\
\text { was treated with } \\
\text { melatonin } 9 \mathrm{mg} \\
\text { p.o./daily at bed } \\
\text { time. }\end{array}$ & $\begin{array}{c}36 \\
\text { months }\end{array}$ & $\begin{array}{l}\text { Neuropsychological } \\
\text { assessment. } \\
\text { Neuroimaging. }\end{array}$ \\
\hline $\begin{array}{l}\text { Open-label, } \\
\text { placebo- } \\
\text { controlled } \\
\text { trial }\end{array}$ & $\begin{array}{l}14 \mathrm{AD} \\
\text { patients }\end{array}$ & $\begin{array}{l}6 \mathrm{mg} \text { melatonin } \\
\text { p.o./daily at bed } \\
\text { time or placebo }\end{array}$ & 4 weeks & $\begin{array}{l}\text { Daily logs of sleep and } \\
\text { wake quality completed by } \\
\text { caretakers. Actigraphy }\end{array}$ \\
\hline
\end{tabular}

Sleep and cognitive function severely impaired in the twin not receiving melatonin as compared to the melatonin-treated twin.

The $7 \mathrm{AD}$ patients receiving melatonin showed a significantly reduced percentage of nighttime activity compared to a placebo group

$\begin{array}{llll}\begin{array}{l}\text { Open-label } \\ \text { study }\end{array} & \begin{array}{l}11(3,8) \mathrm{AD} \\ \text { patients }\end{array} & \begin{array}{l}3 \mathrm{mg} \text { melatonin } \\ \text { p.o./daily at bed } \\ \text { time }\end{array}\end{array}$ 3 weeks $\begin{aligned} & \text { Daily logs of sleep and } \\ & \text { wake quality completed by } \\ & \text { the nurses. }\end{aligned}$

Analysis revealed a significant decrease in agitated behaviors in all three shifts and a significant decrease in daytime sleepiness.

Daily logs of sleep and wake quality completed by

Open-label $45(19,26)$ study AD patients 6-9 mg melatonin p.o./daily at bed 4 months caretakers. time
Neuropsychological assessment.
Melatonin improved sleep and suppressed sundowning, an effect seen regardless of the concomitant medication employed to treat cognitive or behavioral signs of AD.

Randomized

double blind

placebo

patients

cross over

study

Double-

blind, placebocontrolled $20(3,17)$

Placebo or $3 \mathrm{mg}$ study
$\mathrm{AD}$ patients p.o./daily at bed time
$6 \mathrm{mg}$ of slow release melatonin p.o. or placebo at bed time
7 weeks Actigraphy
Melatonin had no effect on median total time asleep, number of awakenings, or sleep efficiency.
[118]

Melatonin significantly prolonged the sleep time and decreased activity in the night. Cognitive function was improved by melatonin.
Randomized, placebo- $157(70,87)$ controlled $\mathrm{AD}$ patients clinical trial
$2.5 \mathrm{mg}$ slow-release

melatonin, or $10 \mathrm{mg}$ melatonin or placebo at bed time
2 months Actigraphy. Caregiver ratings of sleep quality
Nonsignificant trends for increased nocturnal total sleep time and decreased wake after sleep onset were observed in the melatonin groups relative to placebo. On subjective measures, caregiver ratings of sleep quality showed improvement in the $2.5 \mathrm{mg}$ sustained-release melatonin group relative to placebo. 
Table 1: Continued.

\begin{tabular}{|c|c|c|c|c|c|c|}
\hline Design & $\begin{array}{l}\text { Subjects } \\
(\mathrm{M}, \mathrm{F})\end{array}$ & Treatment & $\begin{array}{l}\text { Study's } \\
\text { duration }\end{array}$ & Measured & Results & Reference \\
\hline $\begin{array}{l}\text { Open-label } \\
\text { study }\end{array}$ & $\begin{array}{l}7(4,3) \mathrm{AD} \\
\text { patients }\end{array}$ & $\begin{array}{l}3 \mathrm{mg} \text { melatonin } \\
\text { p.o./daily at bed } \\
\text { time }\end{array}$ & 3 weeks & $\begin{array}{l}\text { Actigraphy. } \\
\text { Neuropsychological } \\
\text { assessment. }\end{array}$ & $\begin{array}{l}\text { Complete remission of daynight } \\
\text { rhythm disturbances or } \\
\text { sundowning was seen in } 4 \text { patients, } \\
\text { with partial remission in other } 2 .\end{array}$ & {$[114]$} \\
\hline $\begin{array}{l}\text { Randomized, } \\
\text { placebo- } \\
\text { controlled } \\
\text { study }\end{array}$ & $\begin{array}{l}17 \mathrm{AD} \\
\text { patients }\end{array}$ & $\begin{array}{l}3 \text { mg melatonin } \\
\text { p.o./daily at bed } \\
\text { time ( } 7 \text { patients). } \\
\text { Placebo ( } 10 \\
\text { patients) }\end{array}$ & 2 weeks & $\begin{array}{l}\text { Actigraphy. } \\
\text { Neuropsychological } \\
\text { assessment. }\end{array}$ & $\begin{array}{l}\text { In melatonin-treated group, } \\
\text { actigraphic nocturnal activity and } \\
\text { agitation showed significant } \\
\text { reductions compared to baseline. }\end{array}$ & {$[121]$} \\
\hline $\begin{array}{l}\text { Randomized, } \\
\text { placebo- } \\
\text { controlled } \\
\text { study }\end{array}$ & $\begin{array}{l}50 \mathrm{AD} \\
\text { patients }\end{array}$ & $\begin{array}{l}\text { Morning light } \\
\text { exposure }(2,500 \\
\text { lux, } 1 \mathrm{~h}) \text { and } 5 \mathrm{mg} \\
\text { melatonin }(n=16) \\
\text { or placebo } \\
(n=17) \text { in the } \\
\text { evening. Control } \\
\text { subjects ( } n=17) \\
\text { received usual } \\
\text { indoor light } \\
(150-200 \text { lux }) .\end{array}$ & 10 weeks & $\begin{array}{l}\text { Night time sleep variables, } \\
\text { day sleep time, day activity, } \\
\text { day: night sleep ratio, and } \\
\text { rest-activity parameters } \\
\text { were determined using } \\
\text { actigraphy. }\end{array}$ & $\begin{array}{l}\text { Light treatment alone did not } \\
\text { improve night time sleep, daytime } \\
\text { wake, or rest-activity rhythm. Light } \\
\text { treatment plus melatonin increased } \\
\text { daytime wake time and activity } \\
\text { levels and strengthened the } \\
\text { rest-activity rhythm. }\end{array}$ & {$[122]$} \\
\hline Case report & $\begin{array}{l}\text { 68-year-old } \\
\text { man with } \\
\text { AD who } \\
\text { developed } \\
\text { rapid eye } \\
\text { movement } \\
\text { (REM) sleep } \\
\text { behavior } \\
\text { disorder }\end{array}$ & $\begin{array}{l}5-10 \text { mg melatonin } \\
\text { p.o./daily at bed } \\
\text { time. }\end{array}$ & $\begin{array}{c}20 \\
\text { months }\end{array}$ & Polysomnography & $\begin{array}{l}\text { Melatonin was effective to suppress } \\
\text { REM sleep behavior disorder }\end{array}$ & {$[123]$} \\
\hline $\begin{array}{l}\text { Randomized, } \\
\text { placebo- } \\
\text { controlled } \\
\text { study }\end{array}$ & $\begin{array}{l}41(13,28) \\
\text { AD patients }\end{array}$ & $\begin{array}{l}\text { Melatonin }(8.5 \mathrm{mg} \\
\text { immediate release } \\
\text { and } 1.5 \mathrm{mg} \\
\text { sustained release }) \\
(N=24) \text { or } \\
\text { placebo }(N=17) \\
\text { administered at } \\
10: 00 \text { P.M. }\end{array}$ & 10 days & Actigraphy. & $\begin{array}{l}\text { There were no significant effects of } \\
\text { melatonin, compared with placebo, } \\
\text { on sleep, circadian rhythms, or } \\
\text { agitation. }\end{array}$ & {$[124]$} \\
\hline
\end{tabular}

was done using melatonin [120]. Because $\mathrm{MT}_{1}$ receptor expression in the SCN is decreased it is certainly possible that melatonin will be ineffective as a synchronizing agent although it is possible that a higher dose of melatonin or a more potent melatonin agonist such as ramelteon may be useful. Another strategy could be exposure to bright light [128] (see below).

\section{Melatonin as a Therapeutic Agent for Mild Cognitive Impairment}

As outlined, melatonin acts at different levels relevant to the development and manifestation of AD. The antioxidant, mitochondrial, and antiamyloidogenic effects may be seen as a possibility of interfering with the onset of the disease. Therefore, early beginning of treatment may be decisive [129].
Mild cognitive impairment (MCI) is an etiologically heterogeneous syndrome characterized by cognitive impairment shown by objective measures adjusted for age and education in advance of dementia [130]. Approximately 12\% of MCI converts to AD or other dementia disorders every year. Since MCI may represent prodromal A,D it should be adequately diagnosed and treated. Indeed, the degenerative process in AD brain starts 20-30 years before the clinical onset of the disease [130]. During this phase, plaques and tangles loads increase and at a certain threshold the first symptom appears. As already mentioned, CSF melatonin levels decrease even in preclinical stages when the patients do not manifest any cognitive impairment (at Braak stages I-II), suggesting that the reduction in CSF melatonin may be an early trigger and marker for AD. Therefore, MCI could be an appropriate moment for initiating any melatonin treatment aiming to affect progression of the disease. Studies on melatonin effect on MCI are summarized in Table 2. 
TABLE 2: Clinical studies on melatonin efficacy in MCI.

\begin{tabular}{|c|c|c|c|c|}
\hline Design & Subjects $(\mathrm{M}, \mathrm{F})$ & Treatment & $\begin{array}{l}\text { Study's } \\
\text { duration }\end{array}$ & Measured \\
\hline $\begin{array}{l}\text { Double-blind, } \\
\text { placebo- } \\
\text { controlled, crossover } \\
\text { study }\end{array}$ & $\begin{array}{l}10(4,6) \\
\text { patients with } \\
\text { mild cognitive } \\
\text { impairment } \\
(\mathrm{MCI})\end{array}$ & $\begin{array}{l}6 \text { mg melatonin } \\
\text { p.o./daily at bed } \\
\text { time }\end{array}$ & 10 days & $\begin{array}{l}\text { Actigraphy. } \\
\text { Neuropsychological } \\
\text { assessment. }\end{array}$ \\
\hline
\end{tabular}

Reference(s)

Enhanced the rest-activity

rhythm and improved sleep

quality (reduced sleep onset

latency and in the number of

transitions from sleep to

wakefulness Total sleep time

unaffected. The ability to

remember previously learned

items improved along with a

significant reduction in

depressed mood.

Melatonin administration

improved reported morning

Double-blind,

26 individuals $1 \mathrm{mg}$ melatonin

placebo-controlled

pilot study

with age-related p.o. or placebo

4 weeks

Sleep questionnaire

and a battery of

MCI at bed time

cognitive tests at

baseline and at 4 weeks

"restedness" and sleep latency

after nocturnal awakening and

also improved scores on the

California Verbal Learning

Test-interference subtest.

Patients treated with

25 had received

daily 3-9 mg of

a fast-release

melatonin

Open-label,

retrospective study

$50(13,37) \mathrm{MCI}$ preparation p.o. outpatients at bedtime.

Melatonin was

given in

addition to the

standard

medication melatonin showed

significantly better

performance in

neuropsychological

assessment. Abnormally high.

Beck Depression Inventory

scores decreased in

melatonin-treated patients,

concomitantly with an

improvement in wakefulness

and sleep quality.

\begin{tabular}{|c|c|c|c|c|c|c|}
\hline $\begin{array}{l}\text { Randomized, double } \\
\text { blind, } \\
\text { placebo-controlled } \\
\text { study }\end{array}$ & $\begin{array}{l}354 \text { individuals } \\
\text { with age-related } \\
\text { cognitive decay }\end{array}$ & $\begin{array}{l}\text { prolonged } \\
\text { release } \\
\text { melatonin } \\
\text { (Circadin, } 2 \mathrm{mg} \text { ) } \\
\text { or placebo, } 2 \mathrm{~h} \\
\text { before bedtime }\end{array}$ & 3 weeks & $\begin{array}{l}\text { Leeds Sleep Evaluation } \\
\text { and Pittsburgh Sleep } \\
\text { Questionnaires, } \\
\text { Clinical Global } \\
\text { Improvement scale } \\
\text { score and quality of } \\
\text { life. }\end{array}$ & $\begin{array}{l}\text { PR-melatonin resulted in } \\
\text { significant and clinically } \\
\text { meaningful improvements in } \\
\text { sleep quality, morning } \\
\text { alertness, sleep onset latency, } \\
\text { and quality of life }\end{array}$ & [134] \\
\hline $\begin{array}{l}\text { Long-term, } \\
\text { double-blind, } \\
\text { placebo-controlled, } \\
2 \times 2 \text { factorial } \\
\text { randomized study }\end{array}$ & $\begin{array}{l}189(19,170) \\
\text { individuals with } \\
\text { age-related } \\
\text { cognitive decay }\end{array}$ & $\begin{array}{l}\text { Long-term daily } \\
\text { treatment with } \\
\text { whole-day } \\
\text { bright ( } 1000 \\
\text { lux) or dim ( } 300 \\
\text { lux) light. } \\
\text { Evening } \\
\text { melatonin } \\
\text { ( } 2.5 \text { mg) or } \\
\text { placebo } \\
\text { administration }\end{array}$ & $\begin{array}{c}1 \text { to } 3.5 \\
\text { years }\end{array}$ & $\begin{array}{l}\text { Standardized scales for } \\
\text { cognitive and } \\
\text { noncognitive } \\
\text { symptoms, limitations } \\
\text { of activities of daily } \\
\text { living, and adverse } \\
\text { effects assessed every } 6 \\
\text { months. }\end{array}$ & $\begin{array}{l}\text { Light attenuated cognitive } \\
\text { deterioration and also } \\
\text { ameliorated depressive } \\
\text { symptoms. Melatonin } \\
\text { shortened sleep onset latency } \\
\text { and increased sleep duration } \\
\text { but adversely affected scores } \\
\text { for depression. The combined } \\
\text { treatment of bright light plus } \\
\text { melatonin showed the best } \\
\text { effects. }\end{array}$ & [105] \\
\hline $\begin{array}{l}\text { Prospective, } \\
\text { randomized, } \\
\text { double-blind, } \\
\text { placebo-controlled, } \\
\text { study }\end{array}$ & $\begin{array}{l}22(15,7) \\
\text { individuals with } \\
\text { age-related } \\
\text { cognitive decay }\end{array}$ & $\begin{array}{l}\text { Participants } \\
\text { received } 2 \\
\text { months of } \\
\text { melatonin ( } 5 \mathrm{mg} \\
\text { o.o./day) and } 2 \\
\text { months of } \\
\text { placebo }\end{array}$ & 2 months & $\begin{array}{l}\text { Sleep disorders were } \\
\text { evaluated with the } \\
\text { Northside Hospital } \\
\text { Sleep Medicine } \\
\text { Institute (NHSMI) test. } \\
\text { Behavioral disorders } \\
\text { were evaluated with the } \\
\text { Yesavage Geriatric } \\
\text { Depression Scale and } \\
\text { Goldberg Anxiety } \\
\text { Scale. }\end{array}$ & $\begin{array}{l}\text { Melatonin treatment } \\
\text { significantly improved sleep } \\
\text { quality scores. Depression also } \\
\text { improved significantly after } \\
\text { melatonin administration. }\end{array}$ & [135] \\
\hline
\end{tabular}


The first report on melatonin treatment of $10 \mathrm{MCI}$ patients $(6 \mathrm{mg} /$ day for 10 days) indicated that besides enhancing the rest-activity rhythm and improved sleep quality the ability to remember previously learned items improved along with a significant reduction in depressed mood [131]. In another double-blind, placebo-controlled pilot study performed in 26 individuals with age-related $\mathrm{MCI}$, the administration of $1 \mathrm{mg}$ melatonin or placebo at bed time for 4 weeks resulted in improvement of sleep and of scores on the California Verbal Learning Test-interference subtest [132].

In a retrospective study of a group of $25 \mathrm{MCI}$ patients who received melatonin (3-9 mg per day) for 9 to 18 months in comparison to a similar group of $25 \mathrm{MCI}$ patients who did not receive it [133], patients treated with melatonin showed significantly better performance in a number of neuropsychological tests. Abnormally high Beck Depression Inventory scores decreased in melatonin treated patients, concomitantly with an improvement in wakefulness and sleep quality. The results suggested that melatonin could be a useful add-on drug for treating MCI in a clinic environment [133]. A follow up of that study has now been completed on a group of $35 \mathrm{MCI}$ patients receiving melatonin for 9 to 24 months with essentially similar results [125].

A randomized controlled trial on the effect of bright light and melatonin on cognitive and noncognitive function in elderly residents of group care facilities was published [105]. The authors concluded that light has a benefit in improving some cognitive and noncognitive symptoms of MCI which was amplified by the conjoint administration of melatonin. In other two similar studies, one of them using the prolonged release preparation of melatonin (Circadin) recently approved by the European Medicines Agency, melatonin resulted in significant and clinically meaningful improvements of sleep quality, morning alertness, sleep onset latency and quality of life in old patients with mild cognitive impairment $[134,135]$. In these studies melatonin treatment also improved mood. The evaluation of the published data concerning melatonin treatment of MCI that include 5 double blind, randomized placebo-controlled trials, and 1 open-label retrospective study $(N=651)$ all agreess in indicating that treatment with daily evening melatonin improves sleep quality and cognitive performance in MCI [125] (Table 2).

\section{Use of Melatonin Agonist, Ramelteon in AD}

As $\mathrm{AD}$ is associated with disturbed sleep/wake rhythms and circadian rhythm disturbances, a melatonin agonist with higher affinity to melatonin $\mathrm{MT}_{1}$ and $\mathrm{MT}_{2}$ receptors with a longer duration would theoretically be beneficial in tackling sleep-wake and circadian rhythm disturbances. In this aspect, ramelteon, which is the first melatonin receptor agonist approved by FDA with activity on $\mathrm{MT}_{1}$ and $\mathrm{MT}_{2}$ receptors, should be considered $[136,137]$.

The chemical structure of ramelteon is: (S)-N-[2(1,6,7,8-tetrahydro-2Hindeno[5,4-b]furan-8-yl)ethyl] propionamide. This melatonin receptor agonist has a chemical formula $\mathrm{C}_{16} \mathrm{H}_{21} \mathrm{NO}_{2}$ with a molecular weight 259.34.
Receptor binding studies indicated that ramelteon has high selectivity for $\mathrm{MT}_{1}$ and $\mathrm{MT}_{2}$ receptors, with little affinity for quinone reductase 2 binding [138]. The selectivity of ramelteon for $\mathrm{MT}_{1}$ has been found $>1000$-fold over that of $\mathrm{MT}_{2}$ receptors. It is well known that melatonin exerts its hypnotic effects through the activation of the $\mathrm{MT}_{1}$ and $\mathrm{MT}_{2}$ melatonin receptors [139]. Although both $\mathrm{MT}_{1}$ and $\mathrm{MT}_{2}$ receptors are involved in the regulation of sleep, the selectivity of $\mathrm{MT}_{1}$ receptors by ramelteon suggests that it targets sleep onset more specifically than melatonin [140]. Ramelteon has been found to have no affinity for benzodiazepine (BZP), dopamine, opiate, or serotonin receptor binding sites [138]. Hence ramelteon has advantages over other hypnotic drugs in not causing rebound insomnia, withdrawal symptoms, or dependence which is common with the activation of BZP, opiate, or dopamine receptors.

On oral administration, ramelteon is rapidly absorbed with a $\mathrm{T}_{\max }$ of less than 1 hour [141]. The absolute bioavailability of the oral formulation of ramelteon is less than $2 \%$ (range $0.5 \%$ to $12 \%$ ) [141]. It is metabolized mainly in the liver via oxidation to hydroxyl and carbonyl groups and then conjugated with glucuronide. CYP1A2 is the major hepatic enzyme involved in ramelteon metabolism. Four principal metabolites ramelteon, that is, M-I, M-II, M-III, and M-IV, have been identified [141]. Among these, M-II has been found to occur in much higher concentration with systemic concentration being 20- to 100 - fold greater than ramelteon.

Ramelteon is rapidly excreted and its elimination is significantly higher in elderly than in younger adults [142]. The influence of age and gender on the pharmacokinetics and pharmacodynamics of ramelteon has been evaluated in healthy volunteers following the administration of a single dose of $16 \mathrm{mg}$ of ramelteon. When compared to young volunteers, ramelteon clearance was significantly reduced in elderly volunteers and its half life significantly increased. No significant effect of gender was observed [142]. The contribution of ramelteon's metabolites on the net pharmacologic activity was also evaluated. Among the four metabolites produced, the activity of M-II was to be about 30-fold lower than that of ramelteon, but its exposure exceeds exposure to ramelteon by a factor 30 . It was thus suggested that M-II may contribute to net clinical activity of ramelteon [142].

The subjective efficacy of ramelteon was evaluated in clinical trials consisting of 829 elderly outpatients with chronic insomnia; 701 patients (128 patients discontinued) were treated for a period of 5-weeks with $4 \mathrm{mg}$ and $8 \mathrm{mg}$ ramelteon [143]. Patients in both ramelteon groups reported significant reductions in sleep onset latency (SOL) and increases in total sleep time (TST). Continuation of this study on 100 elderly patients established the efficacy of ramelteon in improving TST and decreasing SOL [144]. A number of studies have now established the efficacy of ramelteon in treating patients with chronic insomnia [145147].

Concerning the safety and adverse effects with ramelteon, in a double blind placebo controlled study of rebound insomnia (sleep latency after treatment discontinuation) Roth and co-workers [143] evaluated each of the 7 nights 


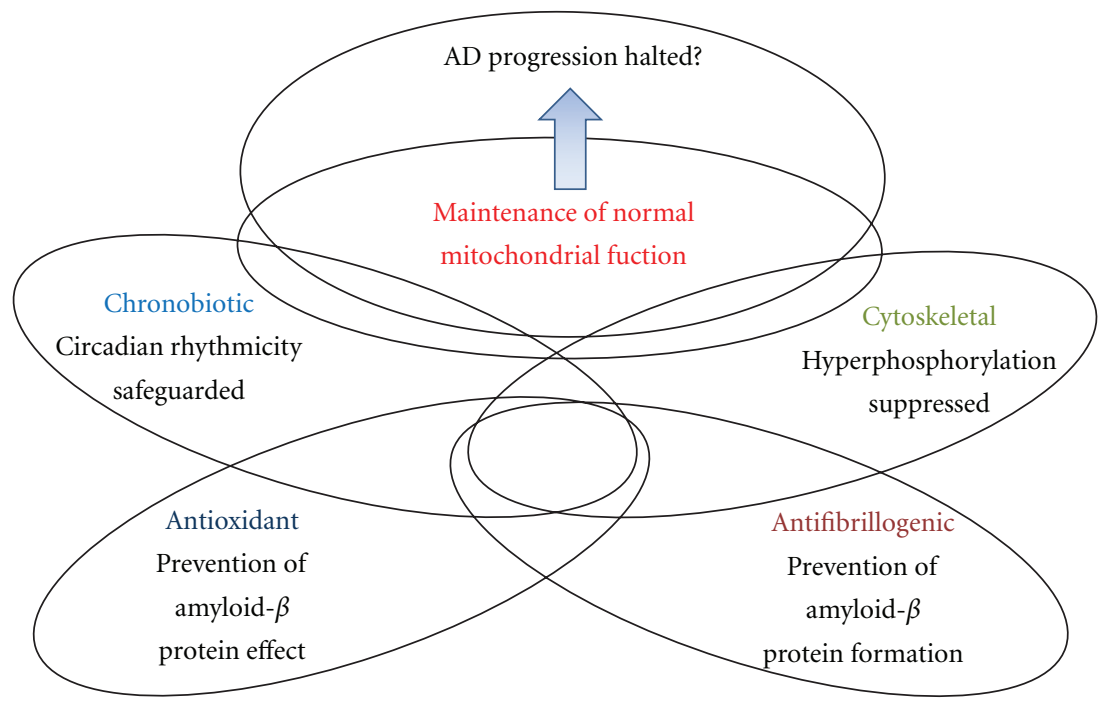

Figure 1: Melatonergic agonists in AD. The multiple effects of melatonin discussed in the text and the different degree of overlap (interrelations and mutual influences) are indicated by the respective intersections in the scheme.

of placebo run-out period. It was noted that during each of the 7 nights, patients in both ramelteon treatment groups ( $4 \mathrm{mg} /$ day and $8 \mathrm{mg} /$ day) maintained a similar or greater reduction in sleep latency from baseline as compared to those receiving placebo [143]. Withdrawal effects, as assessed by a BZP withdrawal symptom questionnaire, did not differ from the placebo group [143]. In another recent study it was noted that ramelteon did not affect alertness or the ability to concentrate, indicating no next-morning residual effects [148]. The incidence of adverse effects in ramelteontreated patients in a 5 week study was found to be similar to that of placebo-treated patients. The adverse effects included mild gastrointestinal disturbances and nervous system effects such as dizziness, headache, somnolence, depression, fatigue, myalgia, and exacerbated eye pain [143].

Ramelteon not only has the potential in improving the sleep quality of $\mathrm{AD}$ and other neurodegenerative patients but can also offer neuroprotection as well in AD [149]. As ramelteon is a melatonin agonist with more potency and longer duration of action, it could act more efficiently than melatonin in its actions against neurotoxic effects involved in the pathogenesis of $\mathrm{AD}$.

To what extent ramelteon reproduces the nonreceptor mediated effects of melatonin is not known. Ramelteon displays no relevant antioxidant capacity in the ABTS radical cation assay, as compared to luzindole or melatonin [150]. However, $\mathrm{MT}_{1} / \mathrm{MT}_{2}$ receptormediated effects on the upregulation of several antioxidant enzymes by physiological concentration of melatonin [151] such as glutathione peroxidase, glutathione reductase, $\gamma$ glutamylcysteine synthase, glucose-6-phosphate dehydrogenase, hemoperoxidase/catalase, $\mathrm{Cu}, \mathrm{Zn}$ - and $\mathrm{Mn}$-superoxide dismutases (reviewed in [152-155] can well give the basis for the use of ramelteon in AD. Since there are extensive data indicating a loss of melatonin receptors in AD patients, including the cerebral cortex and pineal gland $\left(\mathrm{MT}_{1}\right.$ and $\mathrm{MT}_{2}$ receptors) [156], the hippocampus [157] and retina
[158] ( $\mathrm{MT}_{2}$ receptors) and the cerebrovascular system [159], and SCN $[126,128]$ ( $\mathrm{MT}_{1}$ receptors), the chances of alleviating symptoms such as sundowning and disturbed sleep by giving the $\mathrm{MT}_{1} / \mathrm{MT}_{2}$ receptor agonist may vanish in late AD patients.

In addition, it has been suggested that melatonin and its receptors participate in neurodevelopment and regulation of neurotrophic factors [160]. In vitro studies have shown that melatonin promotes the viability and neuronal differentiation of neural stem cells and increases the production brainderived neurotrophic factor (BDNF) by acting through $\mathrm{MT}_{1}$ receptors [161]. In mouse cerebellar granule cells in culture ramelteon increased the neural content of BDNF [162]. Therefore, if ramelteon treatment is capable of regulating brain BDNF levels, it could be used as a possible therapeutic agent in neurodegenerative diseases like $\mathrm{AD}$ for treating symptoms other than sleep disturbances.

\section{Concluding Remarks}

As $\mathrm{AD}$ disease involves a complex physiopathology, it has been suggested that monotherapy targeting early single steps in this complex cascade process may not be of much help [149]. Pleiotrophic drugs that can act independently by different routes including antioxidant, antiinflammatory, and antiamyloid effects would be much beneficial in the treatment of $\mathrm{AD}$ and other neurodegenerative disorders. Available evidence indicates suppression of GSK-3 $\beta$ overactivity; neuroinflammation and mitochondrial impairment are some of the combined strategies required in $\mathrm{AD}$.

Melatonin is a pleiotropic molecule with antioxidant, antiinflammatory and antinitridergic properties [56, 154, 163]. It has also a role in sleep induction, and this is important in view that sleep deprivation is one of the cardinal features seen in $\mathrm{AD}$ and other neurodegenerative diseases. Sleep deprivation is associated with GSK$3 \beta$ activation [164], altered proteosomal processing [165], 
oxidative damage [166], impaired mitochondrial integrity and function [167], and neurodegenerative inflammation [168]. Therefore, improvement of insomnia in neurodegenerative conditions and particularly in $\mathrm{AD}$ is a good practical approach for arresting the progression of the disease (Figure 1).

Melatonin and particularly ramelteon can be greatly beneficial in preventing the insomnia-induced damage of neuronal cells and can be of therapeutic value in treating $\mathrm{AD}$. Owing to its potent effect on $\mathrm{MT}_{1}$ and $\mathrm{MT}_{2}$ receptors, ramelteon activates sleep onset by influencing the hypothalamic "sleep switch" downstream from the SCN more efficiently than melatonin itself [35]. Multicenter, placebo-controlled clinical trials using ramelteon are needed to prove the efficacy of this drug in arresting the progression or prevention of $\mathrm{AD}$ or remission in the early stages of $\mathrm{AD}$ such as MCI.

\section{Acknowledgment}

D. P. Cadinale is a Research Career Awardee from the Argentine National Research Council (CONICET), Argentina.

\section{Conflict of Interest Statement and Disclosure Statement}

S. R. Pandi-Perumal is a stockholder and the President and Chief Executive Office of Somnogen Inc., a New York Corporation. He declared no competing interests that might be perceived to influence the content of this article. All remaining authors declare that they have no proprietary, financial, professional, nor any other personal interest of any kind in any product or services and/or company that could be construed or considered to be a potential conflict of interest that might have influenced the views expressed in this manuscript.

\section{References}

[1] J. J. Palop and L. Mucke, "Amyloid- $\beta$-induced neuronal dysfunction in Alzheimer's disease: from synapses toward neural networks," Nature Neuroscience, vol. 13, no. 7, pp. 812-818, 2010.

[2] M. Mancuso, D. Orsucci, A. LoGerfo, V. Calsolaro, and G. Siciliano, "Clinical features and pathogenesis of Alzheimer's disease: involvement of mitochondria and mitochondrial DNA," Advances in Experimental Medicine and Biology, vol. 685, pp. 34-44, 2010.

[3] C. Behl, J. B. Davis, R. Lesley, and D. Schubert, "Hydrogen peroxide mediates amyloid $\beta$ protein toxicity," Cell, vol. 77, no. 6, pp. 817-827, 1994.

[4] K. Hensley, J. M. Carney, M. P. Mattson et al., "A model for $\beta$ amyloid aggregation and neurotoxicity based on free radical generation by the peptide: relevance to Alzheimer disease," Proceedings of the National Academy of Sciences of the United States of America, vol. 91, no. 8, pp. 3270-3274, 1994.

[5] M. A. Pappolla, Y. J. Chyan, B. Poeggeler et al., "An assessment of the antioxidant and the antiamyloidogenic properties of melatonin: implications for Alzheimer's disease," Journal of Neural Transmission, vol. 107, no. 2, pp. 203231, 2000.

[6] R. H. Swerdlow, J. M. Burns, and S. M. Khan, "The Alzheimer's disease mitochondrial cascade hypothesis," Journal of Alzheimer's Disease, vol. 20, supplement 2, pp. S265S279, 2010.

[7] W. E. Müller, A. Eckert, C. Kurz, G. P. Eckert, and K. Leuner, "Mitochondrial dysfunction: common final pathway in brain aging and Alzheimer's disease-therapeutic aspects," Molecular Neurobiology, vol. 41, no. 2-3, pp. 159-171, 2010.

[8] J. Viña and A. Lloret, "Why women have more Alzheimer's disease than men: gender and mitochondrial toxicity of amyloid- $\beta$ peptide," Journal of Alzheimer's Disease, vol. 20, supplement 2, pp. S527-S533, 2010.

[9] B. F. Oliveira, J. A. Nogueira-Machado, and M. M. Chaves, "The role of oxidative stress in the aging process," Scientific World Journal, vol. 10, pp. 1121-1128, 2010.

[10] A. R. Hipkiss, "Mitochondrial dysfunction, proteotoxicity, and aging: causes or effects, and the possible impact of NAD+-controlled protein glycation," Advances in Clinical Chemistry, vol. 50, pp. 123-150, 2010.

[11] V. Calabrese, C. Cornelius, C. Mancuso, R. Lentile, A. M. Stella, and D. A. Butterfield, "Redox homeostasis and cellular stress response in aging and neurodegeneration," Methods in Molecular Biology, vol. 610, pp. 285-308, 2010.

[12] G. Candore, M. Bulati, C. Caruso et al., "Inflammation, cytokines, immune response, apolipoprotein E, cholesterol, and oxidative stress in alzheimer disease: therapeutic implications," Rejuvenation Research, vol. 13, no. 2-3, pp. 301-313, 2010.

[13] S. Mandrekar-Colucci and G. E. Landreth, "Microglia and inflammation in Alzheimer's disease," CNS and Neurological Disorders-Drug Targets, vol. 9, no. 2, pp. 156-167, 2010.

[14] M. Fiala, "Re-balancing of inflammation and $A \beta$ immunity as a therapeutic for Alzheimer's disease-view from the bedside," CNS and Neurological Disorders-Drug Targets, vol. 9, no. 2, pp. 192-196, 2010.

[15] T. Nakagawa, H. Zhu, N. Morishima et al., "Caspase12 mediates endoplasmic-reticulum-specific apoptosis and cytotoxicity by amyloid- $\beta$," Nature, vol. 403 , no. 6765 , pp. 98-103, 2000.

[16] M. Fotuhi, V. Hachinski, and P. J. Whitehouse, "Changing perspectives regarding late-life dementia," Nature Reviews Neurology, vol. 5, no. 12, pp. 649-658, 2009.

[17] S. Beaulieu-Bonneau and C. Hudon, "Sleep disturbances in older adults with mild cognitive impairment," International Psychogeriatrics, vol. 21, no. 4, pp. 654-666, 2009.

[18] V. Cochen, C. Arbus, M. E. Soto et al., "Sleep disorders and their impacts on healthy, dependent, and frail older adults," Journal of Nutrition, Health and Aging, vol. 13, no. 4, pp. 322329, 2009.

[19] M. F. Vecchierini, "Sleep disturbances in Alzheimer's disease and other dementias," Psychologie et NeuroPsychiatrie du Vieillissement, vol. 8, no. 1, pp. 15-23, 2010.

[20] D. J. Skene, B. Vivient-Roels, D. L. Sparks et al., "Daily variation in the concentration of melatonin and 5methoxytryptophol in the human pineal gland: effect of age and Alzheimer's disease," Brain Research, vol. 528, no. 1, pp. 170-174, 1990.

[21] R. Y. Liu, J. N. Zhou, J. van Heerikhuize, M. A. Hofman, and D. F. Swaab, "Decreased melatonin levels in postmortem cerebrospinal fluid in relation to aging, Alzheimer's disease, and apolipoprotein E- $44 / 4$ genotype," Journal of Clinical 
Endocrinology and Metabolism, vol. 84, no. 1, pp. 323-327, 1999.

[22] K. Mishima, T. Tozawa, K. Satoh, Y. Matsumoto, Y. Hishikawa, and M. Okawa, "Melatonin secretion rhythm disorders in patients with senile dementia of Alzheimer's type with disturbed sleep-waking," Biological Psychiatry, vol. 45, no. 4, pp. 417-421, 1999.

[23] V. Srinivasan, S. R. Pandi-Perumal, D. P. Cardinali, B. Poeggeler, and R. Hardeland, "Melatonin in Alzheimer's disease and other neurodegenerative disorders," Behavioral and Brain Functions, vol. 2, article 15, 2006.

[24] C. Kaur, V. Sivakumar, J. Lu, and E. A. Ling, "Increased vascular permeability and nitric oxide production in response to hypoxia in the pineal gland," Journal of Pineal Research, vol. 42, no. 4, pp. 338-349, 2007.

[25] A. Sakotnik, P. M. Liebmann, K. Stoschitzky et al., "Decreased melatonin synthesis in patients with coronary artery disease," European Heart Journal, vol. 20, no. 18, pp. 1314-1317, 1999.

[26] L. Girotti, M. Lago, O. Ianovsky et al., "Low urinary 6sulphatoxymelatonin levels in patients with coronary artery disease," Journal of Pineal Research, vol. 29, no. 3, pp. 138$142,2000$.

[27] L. Girotti, M. Lago, O. Ianovsky et al., "Low urinary 6sulfatoxymelatonin levels in patients with severe congestive heart failure," Endocrine, vol. 22, no. 3, pp. 245-248, 2003.

[28] C. Peers, H. A. Pearson, and J. P. Boyle, "Hypoxia and Alzheimer's disease," Essays in Biochemistry, vol. 43, pp. 153$164,2007$.

[29] M. Guglielmotto, M. Aragno, R. Autelli et al., "The upregulation of BACE1 mediated by hypoxia and ischemic injury: role of oxidative stress and HIF $1 \alpha$," Journal of Neurochemistry, vol. 108, no. 4, pp. 1045-1056, 2009.

[30] X. Zhang, K. Zhou, R. Wang et al., "Hypoxia-inducible factor $1 \alpha($ HIF- $1 \alpha)$-mediated hypoxia increases BACE1 expression and $\beta$-amyloid generation," Journal of Biological Chemistry, vol. 282, no. 15, pp. 10873-10880, 2007.

[31] X. Zhang and W. Le, "Pathological role of hypoxia in Alzheimer's disease," Experimental Neurology, vol. 223, no. 2, pp. 299-303, 2010.

[32] K.-M. Ng, C.-F. Lau, and M.-L. Fung, "Melatonin reduces hippocampal $\beta$-amyloid generation in rats exposed to chronic intermittent hypoxia," Brain Research, vol. 1354, no. C, pp. 163-171, 2010.

[33] M. Aldhous, C. Franey, J. Wright, and J. Arendt, "Plasma concentrations of melatonin in man following oral absorption of different preparations," British Journal of Clinical Pharmacology, vol. 19, no. 4, pp. 517-521, 1985.

[34] S. A. Ferguson, S. M. W. Rajaratnam, and D. Dawson, "Melatonin agonists and insomnia," Expert Review of Neurotherapeutics, vol. 10, no. 2, pp. 305-318, 2010.

[35] S. R. Pandi-Perumal, V. Srinivasan, D. W. Spence et al., "Ramelteon: a review of its therapeutic potential in sleep disorders," Advances in Therapy, vol. 26, no. 6, pp. 613-626, 2009.

[36] G. M. Brown, D. P. Cardinali, and S. R. Pandi-Perumal, "Melatonin and mental illness," in Sleep and Mental Illness, S. R. Pandi-Perumal and M. Kramer, Eds., Cambridge University Press, Cambridge, UK, 2010.

[37] D. C. Klein, "Arylalkylamine N-acetyltransferase: "the timezyme"', Journal of Biological Chemistry, vol. 282, no. 7, pp. 4233-4237, 2007.
[38] D. C. Klein, M. J. Bailey, D. A. Carter et al., "Pineal function: impact of microarray analysis," Molecular and Cellular Endocrinology, vol. 314, no. 2, pp. 170-183, 2010.

[39] H. Tricoire, A. Locatelli, P. Chemineau, and B. Malpaux, "Melatonin enters the cerebrospinal fluid through the pineal recess," Endocrinology, vol. 143, no. 1, pp. 84-90, 2002.

[40] J. Leston, C. Harthé, J. Brun et al., "Melatonin is released in the third ventricle in humans. A study in movement disorders," Neuroscience Letters, vol. 469, no. 3, pp. 294-297, 2010.

[41] R. J. Reiter and D. X. Tan, "Role of CSF in the transport of melatonin," Journal of Pineal Research, vol. 33, no. 1, article 61, 2002.

[42] S. F. Pang and G. M. Brown, "Regional concentrations of melatonin in the rat brain in the light and dark period," Life Sciences, vol. 33, no. 12, pp. 1199-1204, 1983.

[43] M. D. Catalá, W. B. Quay, and P. S. Timiras, "Lower tryptophan:phenylalanine ratios in culture media increase medium: pineal melatonin ratios in early dark but not late light phase," Journal of Pineal Research, vol. 4, no. 3, pp. 267275, 1987.

[44] D. P. Cardinali, R. E. Rosenstein, D. A. Golombek et al., "Melatonin binding sites in brain: single or multiple?" Advances in Pineal Research, vol. 5, pp. 159-165, 1991.

[45] G. Facciolá, M. Hidestrand, C. von Bahr, and G. Tybring, "Cytochrome P isoforms involved in melatonin metabolism in human liver microsomes," European Journal of Clinical Pharmacology, vol. 56, no. 12, pp. 881-888, 2001.

[46] F. Hirata, O. Hayaishi, T. Tokuyama, and S. Senoh, "In vitro and in vitro formation of two new metabolites of melatonin," Journal of Biological Chemistry, vol. 249, no. 4, pp. 13111313, 1974.

[47] R. Hardeland, D. X. Tan, and R. J. Reiter, "Kynuramines, metabolites of melatonin and other indoles: the resurrection of an almost forgotten class of biogenic amines," Journal of Pineal Research, vol. 47, no. 2, pp. 109-126, 2009.

[48] D. X. Tan, L. C. Manchester, R. J. Reiter et al., "A novel melatonin metabolite, cyclic 3-hydroxymelatonin: a biomarker of in vivo hydroxyl radical generation," Biochemical and Biophysical Research Communications, vol. 253, no. 3, pp. 614-620, 1998.

[49] R. J. Reiter, "The melatonin rhythm: both a clock and a calendar," Experientia, vol. 49, no. 8, pp. 654-664, 1993.

[50] D. Dawson and S. M. Armstrong, "Chronobiotics-drugs that shift rhythms," Pharmacology and Therapeutics, vol. 69, no. 1, pp. 15-36, 1996.

[51] R. J. Wurtman and I. Zhdanova, "Improvement of sleep quality by melatonin," Lancet, vol. 346, no. 8988, p. 1491, 1995.

[52] J. M. Monti, F. Alvariño, D. Cardinali, I. Savio, and A. Pintos, "Polysomnographic study of the effect of melatonin on sleep in elderly patients with chronic primary insomnia," Archives of Gerontology and Geriatrics, vol. 28, no. 2, pp. 85-98, 1999.

[53] A. Carrillo-Vico, R. J. Reiter, P. J. Lardone et al., "The modulatory role of melatonin on immune responsiveness," Current Opinion in Investigational Drugs, vol. 7, no. 5, pp. 423-431, 2006.

[54] V. Srinivasan, G. J. M. Maestroni, D. P. Cardinali, A. I. Esquifino, S. R. Pandi Perumal, and S. C. Miller, "Melatonin, immune function and aging," Immunity and Ageing, vol. 2, article 17, 2005.

[55] R. J. Reiter, J. J. Garcia, and J. Pie, "Oxidative toxicity in models of neurodegeneration: responses to melatonin," 
Restorative Neurology and Neuroscience, vol. 12, no. 2-3, pp. 135-142, 1998.

[56] R. J. Reiter, D. X. Tan, and L. Fuentes-Broto, "Melatonin: a multitasking molecule," Progress in Brain Research, vol. 181, pp. 127-151, 2010.

[57] R. J. Reiter, "The pineal and its hormones in the control of reproduction in mammals," Endocrine Reviews, vol. 1, no. 2, pp. 109-131, 1980.

[58] R. J. Reiter, D. X. Tan, L. C. Manchester, S. D. Paredes, J. C. Mayo, and R. M. Sainz, "Melatonin and reproduction revisited," Biology of Reproduction, vol. 81, no. 3, pp. 445-456, 2009.

[59] V. Srinivasan, W. D. Spence, S. R. Pandi-Perumal, R. Zakharia, K. P. Bhatnagar, and A. Brzezinski, "Melatonin and human reproduction: shedding light on the darkness hormone," Gynecological Endocrinology, vol. 25, no. 12, pp. 779-785, 2009.

[60] D. E. Blask, L. A. Sauer, and R. T. Dauchy, "Melatonin as a chronobiotic/anticancer agent: cellular, biochemical, and molecular mechanisms of action and their implications for circadian-based cancer therapy," Current Topics in Medicinal Chemistry, vol. 2, no. 2, pp. 113-132, 2002.

[61] B. Jung-Hynes, R. J. Reiter, and N. Ahmad, "Sirtuins, melatonin and circadian rhythms: building a bridge between aging and cancer," Journal of Pineal Research, vol. 48, no. 1, pp. 9-19, 2010.

[62] A. J. Lewy, "Circadian misalignment in mood disturbances," Current Psychiatry Reports, vol. 11, no. 6, pp. 459-465, 2009.

[63] S. R. Pandi-Perumal, I. Trakht, G. M. Brown, and D. P. Cardinali, "Melatonin, circadian dysregulation, and sleep in mental disorders," Primary Psychiatry, vol. 15, no. 5, pp. 7782, 2008.

[64] S. M. Reppert, D. R. Weaver, and T. Ebisawa, "Cloning and characterization of a mammalian melatonin receptor that mediates reproductive and circadian responses," Neuron, vol. 13, no. 5, pp. 1177-1185, 1994.

[65] S. M. Reppert, C. Godson, C. D. Mahle, D. R. Weaver, S. A. Slaugenhaupt, and J. F. Gusella, "Molecular characterization of a second melatonin receptor expressed in human retina and brain: the $\mathrm{Mel}(1 \mathrm{~b})$ melatonin receptor," Proceedings of the National Academy of Sciences of the United States of America, vol. 92, no. 19, pp. 8734-8738, 1995.

[66] M. L. Dubocovich, P. Delagrange, D. N. Krause, D. Sugden, D. P. Cardinali, and J. Olcese, "International union of basic and clinical pharmacology. LXXV. Nomenclature, classification, and pharmacology of $\mathrm{G}$ protein-coupled melatonin receptors," Pharmacological Reviews, vol. 62, no. 3, pp. 343$380,2010$.

[67] C. Carlberg and I. Wiesenberg, "The orphan receptor family RZR/ROR, melatonin and 5-lipoxygenase: an unexpected relationship," Journal of Pineal Research, vol. 18, no. 4, pp. 171-178, 1995.

[68] A. M. Jetten, S. Kurebayashi, and E. Ueda, "The ROR nuclear orphan receptor subfamily: critical regulators of multiple biological processes," Progress in Nucleic Acid Research and Molecular Biology, vol. 69, pp. 205-247, 2001.

[69] G. Benítez-King, "Melatonin as a cytoskeletal modulator: implications for cell physiology and disease," Journal of Pineal Research, vol. 40, no. 1, pp. 1-9, 2006.

[70] D. P. Cardinali and F. Freire, "Melatonin effects on brain. Interaction with microtubule protein, inhibition of fast axoplasmic flow and induction of crystaloid and tubular formations in the hypothalamus," Molecular and Cellular Endocrinology, vol. 2, no. 5, pp. 317-330, 1975.
[71] Y. Urata, S. Honma, S. Goto et al., "Melatonin induces $\gamma$ glutamylcysteine synthetase mediated by activator protein-1 in human vascular endothelial cells," Free Radical Biology and Medicine, vol. 27, no. 7-8, pp. 838-847, 1999.

[72] V. Srinivasan, S. R. Pandi-Perumal, G. J. M. Maestroni, A. I. Esquifino, R. Hardeland, and D. P. Cardinali, "Role of melatonin in neurodegenerative diseases," Neurotoxicity Research, vol. 7, no. 4, pp. 293-318, 2005.

[73] C. Kaur and E. A. Ling, "Antioxidants and neuroprotection in the adult and developing central nervous system," Current Medicinal Chemistry, vol. 15, no. 29, pp. 3068-3080, 2008.

[74] M. A. Pappolla, M. Sos, R. A. Omar et al., "Melatonin prevents death of neuroblastoma cells exposed to the Alzheimer amyloid peptide," Journal of Neuroscience, vol. 17, no. 5, pp. 1683-1690, 1997.

[75] M. A. Pappolla, Y. J. Chyan, B. Poeggeler et al., "Alzheimer $\beta$ protein mediated oxidative damage of mitochondrial DNA: prevention by melatonin," Journal of Pineal Research, vol. 27, no. 4, pp. 226-229, 1999.

[76] M. A. Pappolla, M. J. Simovich, T. Bryant-Thomas et al., "The neuroprotective activities of melatonin against the Alzheimer $\beta$-protein are not mediated by melatonin membrane receptors," Journal of Pineal Research, vol. 32, no. 3, pp. 135-142, 2002.

[77] M. Pérez, F. Hernández, A. Gómez-Ramos, M. Smith, G. Perry, and J. Avila, "Formation of aberrant phosphotau fibrillar polymers in neural cultured cells," European Journal of Biochemistry, vol. 269, no. 5, pp. 1484-1489, 2002.

[78] G. Benitez-King, I. Túnez, A. Bellon, G. G. Ortíz, and F. Antón-Tay, "Melatonin prevents cytoskeletal alterations and oxidative stress induced by okadaic acid in N1E-115 cells," Experimental Neurology, vol. 182, no. 1, pp. 151-159, 2003.

[79] K. K. Ting, B. Brew, and G. Guillemin, "The involvement of astrocytes and kynurenine pathway in Alzheimer's disease," Neurotoxicity Research, vol. 12, no. 4, pp. 247-262, 2007.

[80] F. M. Harris, I. Tesseur, W. J. Brecht et al., "Astroglial regulation of apolipoprotein $\mathrm{E}$ expression in neuronal cells: implications for Alzheimer's disease," Journal of Biological Chemistry, vol. 279, no. 5, pp. 3862-3868, 2004.

[81] F. Malchiodi-Albedi, M. R. Domenici, S. Paradisi, A. Bernardo, M. A. Ajmone-Cat, and L. Minghetti, "Astrocytes contribute to neuronal impairment in $\beta$ A toxicity increasing apoptosis in rat hippocampal neurons," GLIA, vol. 34 , no. 1, pp. 68-72, 2001.

[82] Z. Feng and J. T. Zhang, "Protective effect of melatonin on $\beta$ amyloid-induced apoptosis in rat astroglioma c6 cells and its mechanism," Free Radical Biology and Medicine, vol. 37, no. 11, pp. 1790-1801, 2004.

[83] B. Poeggeler, L. Miravalle, M. G. Zagorski et al., "Melatonin reverses the profibrillogenic activity of apolipoprotein E4 on the alzheimer amyloid A $\beta$ peptidet," Biochemistry, vol. 40, no. 49, pp. 14995-15001, 2001.

[84] E. Matsubara, T. Bryant-Thomas, J. P. Quinto et al., "Melatonin increases survival and inhibits oxidative and amyloid pathology in a transgenic model of Alzheimer's disease," Journal of Neurochemistry, vol. 85, no. 5, pp. 1101-1108, 2003.

[85] X. Cheng and R. B. van Breemen, "Mass spectrometry-based screening for inhibitors of $\beta$-amyloid protein aggregation," Analytical Chemistry, vol. 77, no. 21, pp. 7012-7015, 2005.

[86] B. Poeggeler, M. A. Pappolla, R. Hardeland et al., "Indole-3propionate: a potent hydroxyl radical scavenger in rat brain," Brain Research, vol. 815, no. 2, pp. 382-388, 1999. 
[87] Y. J. Chyan, B. Poeggeler, R. A. Omar et al., "Potent neuroprotective properties against the Alzheimer $\beta$-amyloid by an endogenous melatonin-related indole structure, indole-3propionic acid," Journal of Biological Chemistry, vol. 274, no. 31, pp. 21937-21942, 1999.

[88] J. R. Harris and N. G. Milton, "Cholesterol in Alzheimer's disease and other amyloidogenic disorders," Sub-Cellular Biochemistry, vol. 51, pp. 47-75, 2010.

[89] Z. Feng, Y. Chang, Y. Cheng et al., "Melatonin alleviates behavioral deficits associated with apoptosis and cholinergic system dysfunction in the APP 695 transgenic mouse model of Alzheimer's disease," Journal of Pineal Research, vol. 37, no. 2, pp. 129-136, 2004.

[90] J. M. Olcese, C. Cao, T. Mori et al., "Protection against cognitive deficits and markers of neurodegeneration by longterm oral administration of melatonin in a transgenic model of Alzheimer disease," Journal of Pineal Research, vol. 47, no. 1, pp. 82-96, 2009.

[91] X. C. Li, ZE. F. Wang, J. X. Zhang, Q. Wang, and J. Z. Wang, "Effect of melatonin on calyculin A-induced tau hyperphosphorylation," European Journal of Pharmacology, vol. 510, no. 1-2, pp. 25-30, 2005.

[92] X. Yang, Y. Yang, Z. Fu Jr et al., "Melatonin ameliorates alzheimer-like pathological changes and spatial memory retention impairment induced by calyculin A," Journal of Psychopharmacology. In press.

[93] Y. Q. Deng, G. G. Xu, P. Duan, Q. Zhang, and J. Z. Wang, "Effects of melatonin on wortmannin-induced tau hyperphosphorylation," Acta Pharmacologica Sinica, vol. 26, no. 5, pp. 519-526, 2005.

[94] S. J. Liu and J. Z. Wang, "Alzheimer-like tau phosphorylation induced by wortmannin in vivo and its attenuation by melatonin," Acta Pharmacologica Sinica, vol. 23, no. 2, pp. 183-187, 2002.

[95] X. C. Wang, J. Zhang, X. Yu et al., "Prevention of isoproterenol-induced tau hyperphosphorylation by melatonin in the rat," Acta Physiologica Sinica, vol. 57, no. 1, pp. $7-12,2005$.

[96] G. Olivieri, U. Otten, F. Meier et al., " $\beta$-amyloid modulates tyrosine kinase B receptor expression in SHSY5Y neuroblastoma cells: influence of the antioxidant melatonin," Neuroscience, vol. 120, no. 3, pp. 659-665, 2003.

[97] J. B. Hoppe, R. L. Frozza, A. P. Horn et al., "Amyloid- $\beta$ neurotoxicity in organotypic culture is attenuated by melatonin: involvement of GSK-3 $\beta$, tau and neuroinflammation," Journal of Pineal Research, vol. 48, no. 3, pp. 230-238, 2010.

[98] A. M. Furio, R. A. Cutrera, V. C. Thea et al., "Effect of melatonin on changes in locomotor activity rhythm of Syrian hamsters injected with beta amyloid peptide 2535 in the suprachiasmatic nuclei," Cellular and Molecular Neurobiology, vol. 22, no. 5-6, pp. 699-709, 2002.

[99] D. A. Weldemichael and G. T. Grossberg, "Circadian rhythm disturbances in patients with Alzheimer's disease: a review," International Journal of Alzheimer's Disease, vol. 2010, Article ID 716453, 2010.

[100] D. G. Harper, E. G. Stopa, A. C. McKee et al., "Differential circadian rhythm disturbances in men with Alzheimer disease and frontotemporal degeneration," Archives of General Psychiatry, vol. 58, no. 4, pp. 353-360, 2001.

[101] E. J. W. van Someren, "Circadian and sleep disturbances in the elderly," Experimental Gerontology, vol. 35, no. 9-10, pp. 1229-1237, 2000.

[102] E. J. W. van Someren, "More than a marker: interaction between the circadian regulation of temperature and sleep, age-related changes, and treatment possibilities," Chronobiology International, vol. 17, no. 3, pp. 313-354, 2000.

[103] S. Klaffke and J. Staedt, "Sundowing and circadian rhythm disorders in dementia," Acta Neurologica Belgica, vol. 106, no. 4, pp. 168-175, 2006.

[104] S. R. Pandi-Perumal, L. K. Seils, L. Kayumov et al., "Senescence, sleep, and circadian rhythms," Ageing Research Reviews, vol. 1, no. 3, pp. 559-604, 2002.

[105] R. F. Riemersma-van der Lek, D. F. Swaab, J. Twisk, E. M. Hol, W. J. G. Hoogendijk, and E. J. W. van Someren, "Effect of bright light and melatonin on cognitive and noncognitive function in elderly residents of group care facilities: a randomized controlled trial," Journal of the American Medical Association, vol. 299, no. 22, pp. 2642-2655, 2008.

[106] Y. Ohashi, N. Okamoto, K. Uchida, M. Iyo, N. Mori, and Y. Morita, "Daily rhythm of serum melatonin levels and effect of light exposure in patients with dementia of the Alzheimer's type," Biological Psychiatry, vol. 45, no. 12, pp. 1646-1652, 1999.

[107] J. N. Zhou, R. Y. Liu, W. Kamphorst, M. A. Hofman, and D. F. Swaab, "Early neuropathological Alzheimer's changes in aged individuals are accompanied by decreased cerebrospinal fluid melatonin levels," Journal of Pineal Research, vol. 35, no. 2, pp. 125-130, 2003.

[108] D. J. Skene and D. F. Swaab, "Melatonin rhythmicity: effect of age and Alzheimer's disease," Experimental Gerontology, vol. 38, no. 1-2, pp. 199-206, 2003.

[109] F. Magri, M. Locatelli, G. Balza et al., "Changes in endocrine circadian rhythms as markers of physiological and pathological brain aging," Chronobiology International, vol. 14, no. 4, pp. 385-396, 1997.

[110] S. M. McCurry, C. F. Reynolds, S. Ancoli-Israel, L. Teri, and M. V. Vitiello, "Treatment of sleep disturbance in Alzheimer's disease," Sleep Medicine Reviews, vol. 4, no. 6, pp. 603-628, 2000.

[111] L. I. Brusco, M. Marquez, and D. P. Cardinali, "Melatonin treatment stabilizes chronobiologic and cognitive symptoms in Alzheimer's disease," Neuroendocrinology Letters, vol. 19, no. 3, pp. 111-115, 1998.

[112] L. I. Brusco, M. Márquez, and D. P. Cardinali, "Monozygotic twins with alzheimer's disease treated with melatonin: case report," Journal of Pineal Research, vol. 25, no. 4, pp. 260-263, 1998.

[113] K. Mishima, M. Okawa, S. Hozumi, and Y. Hishikawa, "Supplementary administration of artificial bright light and melatonin as potent treatment for disorganized circadian rest-activity and dysfunctional autonomic and neuroendocrine systems in institutionalized demented elderly persons," Chronobiology International, vol. 17, no. 3, pp. 419432, 2000.

[114] R. Mahlberg, D. Kunz, I. Sutej, K. P. Kühl, and R. Hellweg, "Melatonin treatment of day-night rhythm disturbances and sundowning in Alzheimer disease: an open-label pilot study using actigraphy," Journal of Clinical Psychopharmacology, vol. 24, no. 4, pp. 456-459, 2004.

[115] D. P. Cardinali, L. I. Brusco, C. Liberczuk, and A. M. Furio, "The use of melatonin in Alzheimer's disease," Neuroendocrinology Letters, vol. 23, no. 1, pp. 20-23, 2002.

[116] I. Fainstein, A. J. Bonetto, L. I. Brusco, and D. P. Cardinali, "Effects of melatonin in elderly patients with sleep disturbance: a pilot study," Current Therapeutic Research-Clinical and Experimental, vol. 58, no. 12, pp. 990-1000, 1997.

[117] J. Cohen-Mansfield, D. Garfinkel, and S. Lipson, "Melatonin for treatment of sundowning in elderly persons with 
dementia-a preliminary study," Archives of Gerontology and Geriatrics, vol. 31, no. 1, pp. 65-76, 2000.

[118] M. Serfaty, S. Kennell-Webb, J. Warner, R. Blizard, and P. Raven, "Double blind randodmised placebo controlled trial of low dose melatonin for sleep disorders in dementia," International Journal of Geriatric Psychiatry, vol. 17, no. 12, pp. 1120-1127, 2002.

[119] K. Asayama, H. Yamadera, T. Ito, H. Suzuki, Y. Kudo, and S. Endo, "Double blind study of melatonin effects on the sleep-wake rhythm, cognitive and non-cognitive functions in Alzheimer type dementia," Journal of Nippon Medical School, vol. 70, no. 4, pp. 334-341, 2003.

[120] C. Singer, R. E. Tractenberg, J. Kaye et al., "A multicenter, placebo-controlled trial of melatonin for sleep disturbance in Alzheimer's disease," Sleep, vol. 26, no. 7, pp. 893-901, 2003.

[121] R. Mahlberg and S. Walther, "Actigraphy in agitated patients with dementia: monitoring treatment outcomes," Zeitschrift fur Gerontologie und Geriatrie, vol. 40, no. 3, pp. 178-184, 2007.

[122] G. A. Dowling, R. L. Burr, E. J. W. van Someren et al., "Melatonin and bright-light treatment for rest-activity disruption in institutionalized patients with Alzheimer's disease," Journal of the American Geriatrics Society, vol. 56, no. 2, pp. 239-246, 2008.

[123] K. N. Anderson, S. Jamieson, A. J. Graham, and J. M. Shneerson, "REM sleep behaviour disorder treated with melatonin in a patient with Alzheimer's disease," Clinical Neurology and Neurosurgery, vol. 110, no. 5, pp. 492-495, 2008.

[124] P. R. Gehrman, D. J. Connor, J. L. Martin, T. Shochat, J. Corey-Bloom, and S. Ancoli-Israel, "Melatonin fails to improve sleep or agitation in double-blind randomized placebo-controlled trial of institutionalized patients with alzheimer disease," American Journal of Geriatric Psychiatry, vol. 17, no. 2, pp. 166-169, 2009.

[125] D. P. Cardinali, A. M. Furio, and L. I. Brusco, "Clinical aspects of melatonin intervention in Alzheimer's disease progression," Current Neuropharmacology, vol. 8, no. 3, pp. 218-227, 2010.

[126] Y. H. Wu, J. N. Zhou, J. van Heerikhuize, R. Jockers, and D. F. Swaab, "Decreased MT1 melatonin receptor expression in the suprachiasmatic nucleus in aging and Alzheimer's disease," Neurobiology of Aging, vol. 28, no. 8, pp. 1239-1247, 2007.

[127] Y. H. Wu, D. F. Fischer, A. Kalsbeek et al., "Pineal clock gene oscillation is disturbed in Alzheimer's disease, due to functional disconnection from the "master clock"," The FASEB Journal, vol. 20, no. 11, pp. 1874-1876, 2006.

[128] Y. H. Wu and D. F. Swaab, "Disturbance and strategies for reactivation of the circadian rhythm system in aging and Alzheimer's disease," Sleep Medicine, vol. 8, no. 6, pp. 623636, 2007.

[129] J. Quinn, D. Kulhanek, J. Nowlin et al., "Chronic melatonin therapy fails to alter amyloid burden or oxidative damage in old Tg2576 mice: implications for clinical trials," Brain Research, vol. 1037, no. 1-2, pp. 209-213, 2005.

[130] S. Gauthier, B. Reisberg, M. Zaudig et al., "Mild cognitive impairment," Lancet, vol. 367, no. 9518, pp. 1262-1270, 2006.

[131] G. Jean-Louis, H. von Gizycki, and F. Zizi, "Melatonin effects on sleep, mood, and cognition in elderly with mild cognitive impairment," Journal of Pineal Research, vol. 25, no. 3, pp. 177-183, 1998.

[132] J. S. Peck, D. B. LeGoff, I. Ahmed, and D. Goebert, "Cognitive effects of exogenous melatonin administration in elderly persons: a pilot study," American Journal of Geriatric Psychiatry, vol. 12, no. 4, pp. 432-436, 2004.

[133] A. M. Furio, L. I. Brusco, and D. P. Cardinali, "Possible therapeutic value of melatonin in mild cognitive impairment: a retrospective study," Journal of Pineal Research, vol. 43, no. 4, pp. 404-409, 2007.

[134] A. G. Wade, I. Ford, G. Crawford et al., "Efficacy of prolonged release melatonin in insomnia patients aged 55-80 years: quality of sleep and next-day alertness outcomes," Current Medical Research and Opinion, vol. 23, no. 10, pp. 2597-2605, 2007.

[135] C. Garzón, J. M. Guerrero, O. Aramburu, and T. Guzmán, "Effecf of melatonin administration on sleep, behavioral disorders and hypnotic drug discontinuation in the elderly: a randomized, double-blind, placebo-controlled study," Aging-Clinical and Experimental Research, vol. 21, no. 1, pp. 38-42, 2009.

[136] M. Miyamoto, "Pharmacology of ramelteon, a selective MT/MT receptor agonist: a novel therapeutic drug for sleep disorders," CNS Neuroscience and Therapeutics, vol. 15, no. 1, pp. 32-51, 2009.

[137] E. J. Sanchez-Barcelo, C. M. Martinez-Campa, M. D. Mediavilla et al., "Melatonin and melatoninergic drugs as therapeutic agents: ramelteon and agomelatine, the two most promising melatonin receptor agonists," Recent Patents on Endocrine, Metabolic \& Immune Drug Discovery, vol. 1, pp. 142-151, 2007.

[138] K. Kato, K. Hirai, K. Nishiyama et al., "Neurochemical properties of ramelteon (TAK-375), a selective $\mathrm{MT}_{1} / \mathrm{MT}_{2}$ receptor agonist," Neuropharmacology, vol. 48, no. 2, pp. 301310, 2005.

[139] N. Zisapel, "Sleep and sleep disturbances: biological basis and clinical implications," Cellular and Molecular Life Sciences, vol. 64, no. 10, pp. 1174-1186, 2007.

[140] C. Cajochen, “TAK-375 Takeda," Current Opinion in Investigational Drugs, vol. 6, no. 1, pp. 114-121, 2005.

[141] S. Stevenson, S. Bryson, D. Amayke et al., "Study to investigate the absolute bioavailability of a single oral dose of ramelteon (TAK-375) in healthy male subjects," Clinical Pharmacology and Therapeutics, vol. 75, p. P22, 2004.

[142] D. J. Greenblatt, J. S. Harmatz, and A. Karim, "Age and gender effects on the pharmacokinetics and pharmacodynamics of ramelteon, a hypnotic agent acting via melatonin receptors $\mathrm{MT}_{1}$ and $\mathrm{MT}_{2}$," Journal of Clinical Pharmacology, vol. 47, no. 4, pp. 485-496, 2007.

[143] T. Roth, D. Seiden, S. Sainati, S. Wang-Weigand, J. Zhang, and P. Zee, "Effects of ramelteon on patient-reported sleep latency in older adults with chronic insomnia," Sleep Medicine, vol. 7, no. 4, pp. 312-318, 2006.

[144] T. Roth, D. Seiden, S. Wang-Weigand, and J. Zhang, "A 2-night, 3-period, crossover study of ramelteon's efficacy and safety in older adults with chronic insomnia," Current Medical Research and Opinion, vol. 23, no. 5, pp. 1005-1014, 2007.

[145] G. Zammit, M. Erman, S. Wang-Weigand, S. Sainati, J. Zhang, and T. Roth, "Evaluation of the efficacy and safety of ramelteon in subjects with chronic insomnia," Journal of Clinical Sleep Medicine, vol. 3, no. 5, pp. 495-504, 2007.

[146] G. Zammit, H. Schwartz, T. Roth, S. Wang-Weigand, S. Sainati, and J. Zhang, "The effects of ramelteon in a firstnight model of transient insomnia," Sleep Medicine, vol. 10, no. 1, pp. 55-59, 2009.

[147] G. Mayer, S. Wang-Weigand, B. Roth-Schechter, R. Lehmann, C. Staner, and M. Partinen, "Efficacy and safety of 6-month 
nightly ramelteon administration in adults with chronic primary insomnia," Sleep, vol. 32, no. 3, pp. 351-360, 2009.

[148] M. Kryger, S. Wang-Weigand, and T. Roth, "Safety of ramelteon in individuals with mild to moderate obstructive sleep apnea," Sleep and Breathing, vol. 11, no. 3, pp. 159-164, 2007.

[149] E. C. Lauterbach, J. Victoroff, K. L. Coburn, S. D. Shillcutt, S. M. Doonan, and M. F. Mendez, "Psychopharmacological neuroprotection in neurodegenerative disease: assessing the preclinical data," Journal of Neuropsychiatry and Clinical Neurosciences, vol. 22, no. 1, pp. 8-18, 2010.

[150] A. M. Mathes, D. Kubulus, L. Waibel et al., "Selective activation of melatonin receptors with ramelteon improves liver function and hepatic perfusion after hemorrhagic shock in rat," Critical Care Medicine, vol. 36, no. 10, pp. 2863-2870, 2008.

[151] D. Tan, R. J. Reiter, L. Chen, B. Poeggeler, L. C. Manchester, and L. R. Barlow-Walden, "Both physiological and pharmacological levels of melatonin reduce DNA adduct formation induced by the carcinogen safrole," Carcinogenesis, vol. 15, no. 2, pp. 215-218, 1994.

[152] R. J. Reiter, D. X. Tan, J. C. Mayo, R. M. Sainz, J. Leon, and Z. Czarnocki, "Melatonin as an antioxidant: biochemical mechanisms and pathophysiological implications in humans," Acta Biochimica Polonica, vol. 50, no. 4, pp. 1129-1146, 2003.

[153] R. Hardeland and S. R. Pandi-Perumal, "Melatonin, a potent agent in antioxidative defense: actions as a natural food constituent, gastrointestinal factor, drug and prodrug," Nutrition and Metabolism, vol. 2, article 22, 2005.

[154] S. R. Pandi-Perumal, V. Srinivasan, G. J. M. Maestroni, D. P. Cardinali, B. Poeggeler, and R. Hardeland, "Melatonin: nature's most versatile biological signal?" FEBS Journal, vol. 273, no. 13, pp. 2813-2838, 2006.

[155] R. Hardeland and B. Poeggeler, "Melatonin beyond its classical functions," Open Physiology Jounal, vol. 1, pp. 1-23, 2008.

[156] P. Brunner, N. Sözer-Topcular, R. Jockers et al., "Pineal and cortical melatonin receptors $\mathrm{MT}_{1}$ and $\mathrm{MT}_{1}$ are decreased in Alzheimer's disease," European Journal of Histochemistry, vol. 50, no. 4, pp. 311-316, 2006.

[157] E. Savaskan, M. A. Ayoub, R. Ravid et al., "Reduced hippocampal $\mathrm{MT}_{2}$ melatonin receptor expression in Alzheimer's disease," Journal of Pineal Research, vol. 38, no. 1, pp. 10-16, 2005.

[158] E. Savaskan, R. Jockers, M. Ayoub et al., "The $\mathrm{MT}_{2}$ melatonin receptor subtype is present in human retina and decreases in Alzheimer's disease," Current Alzheimer Research, vol. 4, no. 1, pp. 47-51, 2007.

[159] E. Savaskan, G. Olivieri, L. Brydon et al., "Cerebrovascular melatonin $\mathrm{MT}_{1}$-receptor alterations in patients with Alzheimer's disease," Neuroscience Letters, vol. 308, no. 1, pp. 9-12, 2001.

[160] L. P. Niles, K. J. Armstrong, L. M. Rincón Castro et al., "Neural stem cells express melatonin receptors and neurotrophic factors: colocalization of the $\mathrm{MT}_{1}$ receptor with neuronal and glial markers," BMC Neuroscience, vol. 5, article 41, 2004.

[161] X. Kong, X. Li, Z. Cai et al., "Melatonin regulates the viability and differentiation of rat midbrain neural stem cells," Cellular and Molecular Neurobiology, vol. 28, no. 4, pp. 569-579, 2008.

[162] M. Imbesi, T. Uz, S. Dzitoyeva, and H. Manev, "Stimulatory effects of a melatonin receptor agonist, ramelteon, on BDNF in mouse cerebellar granule cells," Neuroscience Letters, vol. 439, no. 1, pp. 34-36, 2008.

[163] R. E. Rosenstein, S. R. Pandi-Perumal, V. Srinivasan, D. W. Spence, G. M. Brown, and D. P. Cardinali, "Melatonin as a therapeutic tool in ophthalmology: implications for glaucoma and uveitis," Journal of Pineal Research, vol. 49, no. 1, pp. 1-13, 2010.

[164] F. Benedetti, A. Serretti, C. Colombo, C. Lorenzi, V. Tubazio, and E. Smeraldi, "A glycogen synthase kinase 3- $\beta$ promoter gene single nucleotide polymorphism is associated with age at onset and response to total sleep deprivation in bipolar depression," Neuroscience Letters, vol. 368, no. 2, pp. 123-126, 2004.

[165] A. Sehgal, W. Joiner, A. Crocker et al., "Molecular analysis of sleep: wake cycles in Drosophila," Cold Spring Harbor Symposia on Quantitative Biology, vol. 72, pp. 557-564, 2007.

[166] L. Lavie and P. Lavie, "Molecular mechanisms of cardiovascular disease in OSAHS: the oxidative stress link," European Respiratory Journal, vol. 33, no. 6, pp. 1467-1484, 2009.

[167] C. Cirelli and G. Tononi, "Uncoupling proteins and sleep deprivation," Archives Italiennes de Biologie, vol. 142, no. 4, pp. 541-549, 2004.

[168] C. Cirelli, U. Faraguna, and G. Tononi, "Changes in brain gene expression after long-term sleep deprivation," Journal of Neurochemistry, vol. 98, no. 5, pp. 1632-1645, 2006. 


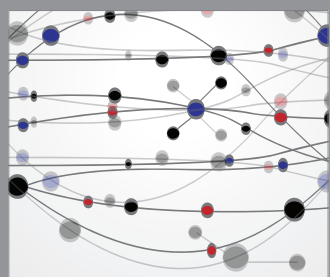

The Scientific World Journal
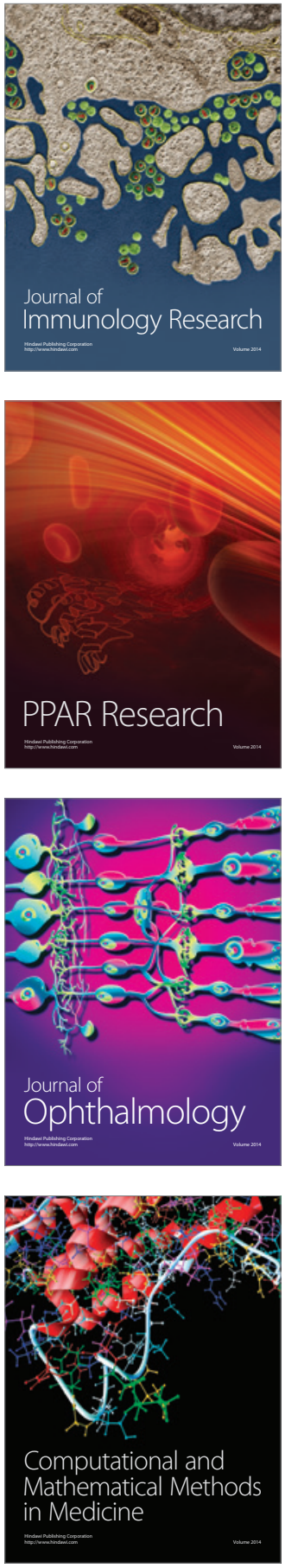

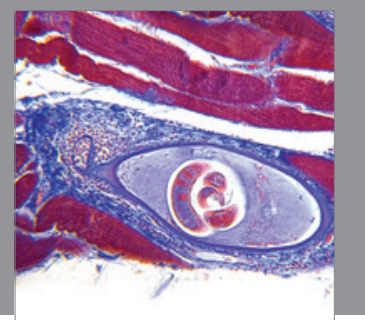

Gastroenterology

Research and Practice
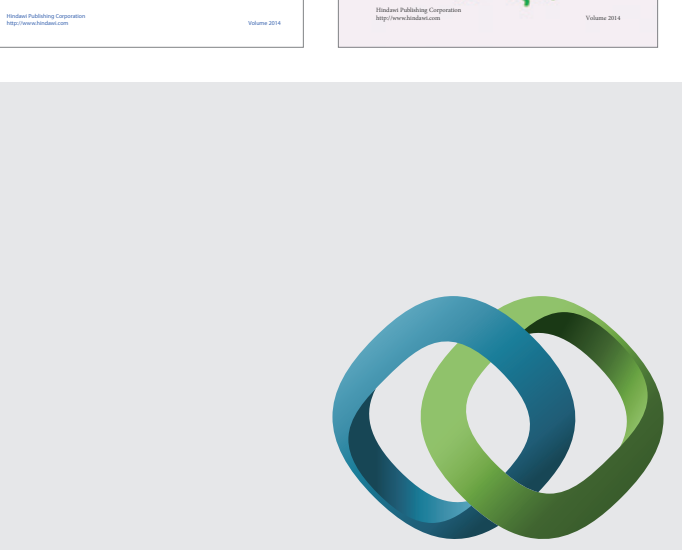

\section{Hindawi}

Submit your manuscripts at

http://www.hindawi.com
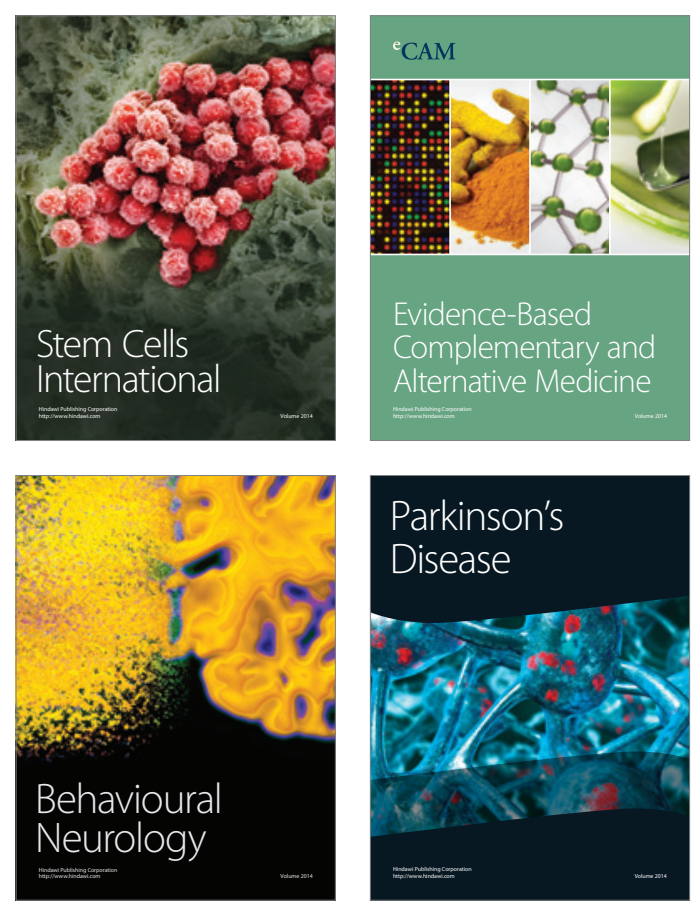

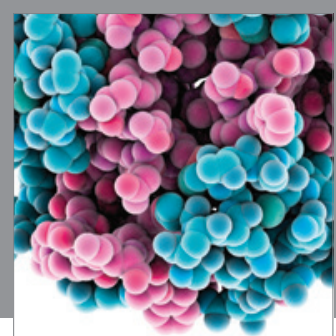

Journal of
Diabetes Research

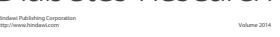

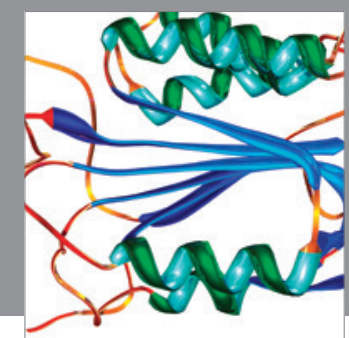

Disease Markers
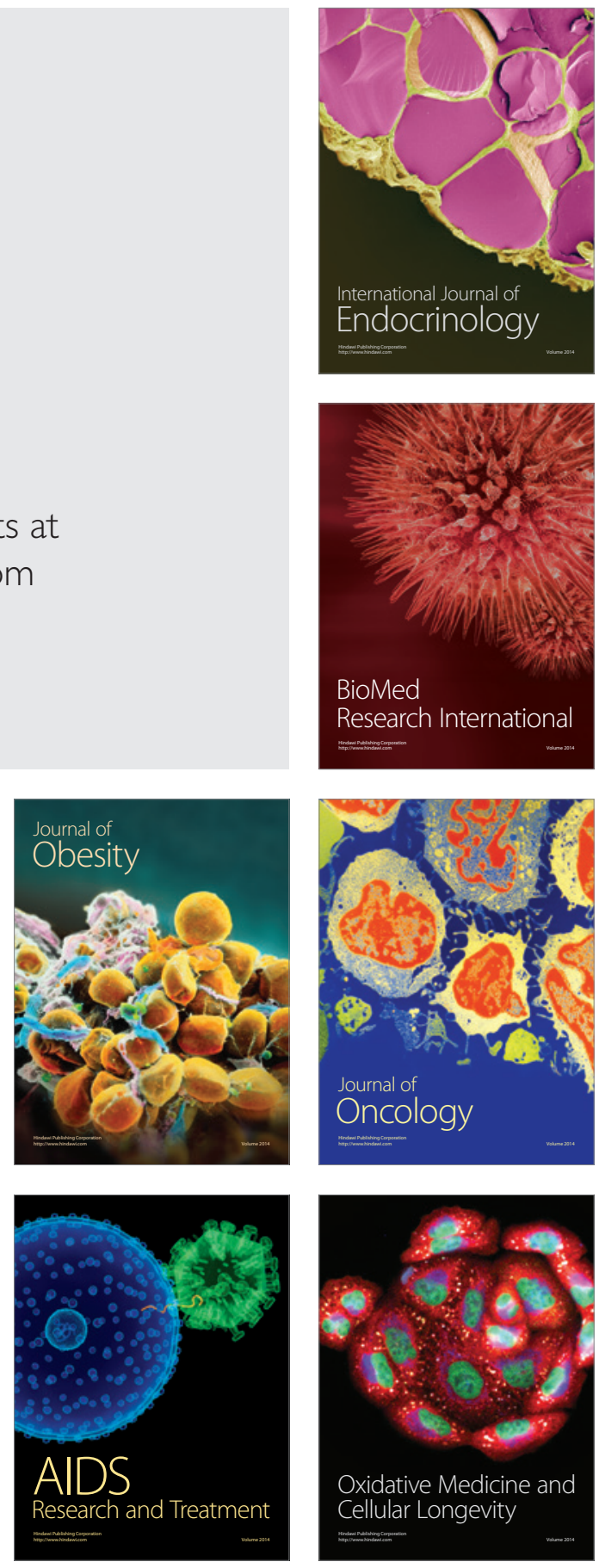